\title{
Quantitative analysis of accommodation patterns in carbonate platforms: an example from the mid-Cretaceous of SE Spain
}

\author{
Javier Martín-Chivelet * \\ Departamento de Estratigrafia, Instituto de Geología Económica (CSIC-UCM), Facultad de Ciencias Geológicas, \\ Universidad Complutense, 28040 Madrid, Spain
}

\begin{abstract}
For sequence stratigraphic analysis of extensive carbonate platforms (hundreds of kilometres wide) developed in greenhouse climates on broad, passive margins, less emphasis should be placed on large-scale seismic geometries, and more attention paid to sequence stratigraphic correlation of stratigraphic sections based usually on isolated outcrops. To this end, quantitative analysis of accommodation emerges as a simple, useful tool, that allows detailed architectural reconstructions, regional chronostratigraphical correlation and systems tract interpretation. In this paper, a quantitative analysis of accommodation was applied to the wide platforms that developed in the southern passive continental margin of Iberia during the mid-Cretaceous (late Albian to early middle Cenomanian interval). This analysis was based on several integrated techniques including: (1) construction of total accommodation curves with the aid of backstripping techniques for calculating decompacted sedimentary accumulation through time, (2) mathematical analysis of these curves and characterisation of second- and third-order accommodation patterns, and (3) analysis of parasequence stacking patterns in peritidal cyclic successions by means of Fischer plots. By applying these techniques to eight individual sections logged at the decimetre scale in outcrops of the External Zones of the Betic orogenic belt, it was possible to characterise the second- and third-order accommodation signal for this interval in the basin. The second-order curve defines a long-term sigmoidal pattern of nearly six million years, with low rates of accommodation generation in the first and the last part of the interval, and high rates in the mid-interval. The third-order signal defines six accommodation events of one million years average duration, which controlled the development of six successive depositional sequences and their systems tracts. On the basis of this new sequence stratigraphic framework, a high-resolution, 2-D platform transect, showing the spatial distribution of facies, was erected and analysed. The results notably complete previous qualitative sequence stratigraphic data on the platform and contribute to a better understanding of the nature of systems tracts and their boundaries in response to overlapping of second- and third-order accommodation patterns.
\end{abstract}

Keywords: carbonate platform; quantitative sequence stratigraphy; accommodation; Fischer plots; Cretaceous; SE Spain

\section{Introduction}

* Tel.: +34-91-3944817; Fax: +34-91-3944808.

E-mail address: j.m.chivelet@geo.ucm.es (J. Martín-Chivelet).

In carbonate platform research, much effort has been focused on applying sequence stratigraphic 
techniques to the carbonate rock record (e.g. Crevello et al., 1989; Sarg, 1989; Tucker et al., 1993; Loucks and Sarg, 1993; Haq, 1995; Wright and Burchette, 1996; de Graciansky et al., 1998), yet attempts to apply basic methods of defining depositional sequences and systems tracts to the analysis of ancient, huge, carbonate platforms have met with major difficulties.

These platforms, hundreds of kilometres wide, were developed mainly on broad, lower plate, thermally-subsiding passive margins under greenhouse climatic conditions such as those prevailing during the Cretaceous. They do not have good analogues in the present day ice-house world. In addition, many such platforms were subsequently thrust and folded during the destruction of passive margins, and incorporated into orogenic belts. In these cases, the geological record of the platforms can be very incomplete, mainly consisting of isolated outcrops many kilometres apart.

For the sequence stratigraphic analysis of these ancient widespread platforms, less emphasis should be placed on stratal geometries (large-scale patterns recognisable in seismic sections or in exceptionally well preserved, smaller-scale, platforms) but more attention paid to sequence stratigraphic correlation of individual sections logged on usually isolated outrops (e.g. Osleger and Read, 1993). Such correlation has been too of ten based on vertical palaeobathymetric trends - deduced from detailed sedimentological and palaeoecological studies - which were considered proxies of accommodation changes (i.e. relative sea-level variations). However, these patterns of variation in accommodation must be inferred not only from water-depth estimates but also from sedimentary accumulation rates. In carbonate settings, these are mainly controlled by organic carbonate production, which is strongly related to changes in water-depth (e.g. Schlager, 1992).

This paper presents a quantitative approach to this type of sequence stratigraphic analysis, and is illustrated by a mid-Cretaceous carbonate platform of the Mesozoic southern passive continental margin of Iberia (Fig. la). To quantify both accommodation and accumulation changes, a combination of different techniques is proposed and applied to individual sections of the platform.
These include: (1) calculation of accumulation rates corrected for compaction, (2) construction of accommodation curves, (3) mathematical analysis and modelling of the accommodation curves, and (4) analysis of parasequence stacking patterns in peritidal cyclic units by means of Fischer plots. All the techniques and mathematical procedures used are extremely simple. Their application to stratigraphic sections is easy and relatively quick, and the results obtained are particularly useful in sequence stratigraphic studies, enabling the construction of regional, high-resolution, chronostratigraphic frameworks on which to base detailed facies pattern reconstruction.

\section{The mid-Cretaceous platform of the Betic margin}

The field work for this study was concentrated in the Jumilla-Yecla Region (SE Spain; Fig. 1b). This area is centred in the Prebetic Zone, a broad tectonic unit that corresponds to the most external portion of the foreland fold-and-thrust belt of the Betic orogenic belt. Here, the carbonate platforms that developed during the Cretaceous on the southern continental margin of the Iberian Plate (the so-called Betic margin) probably present their most complete record, cropping out in SW-NE elongated sierras separated by Quaternary alluvial fans and wadi-like plains.

The tectonosedimentary evolution of these platforms, recently summarised by Vilas et al. (1998) and Martín-Chivelet et al. (2002), indicates that the ancient continental margin was strongly affected by intraplate stresses that modified broad thermal subsidence and punctuated its history with a series of relatively short tectonic pulses or events that episodically changed the regional palaeogeography. These tectonic pulses are marked in the sedimentary record by regional unconformities, which enable the definition of a series of major allostratigraphic units (herein called sequence sets) of average duration 4-6 Ma (Fig. 2a). Within each of these unconformity-bounded units, several third-order depositional sequences and related relative sea-level changes can be recognised (Martín-Chivelet, 1995). 

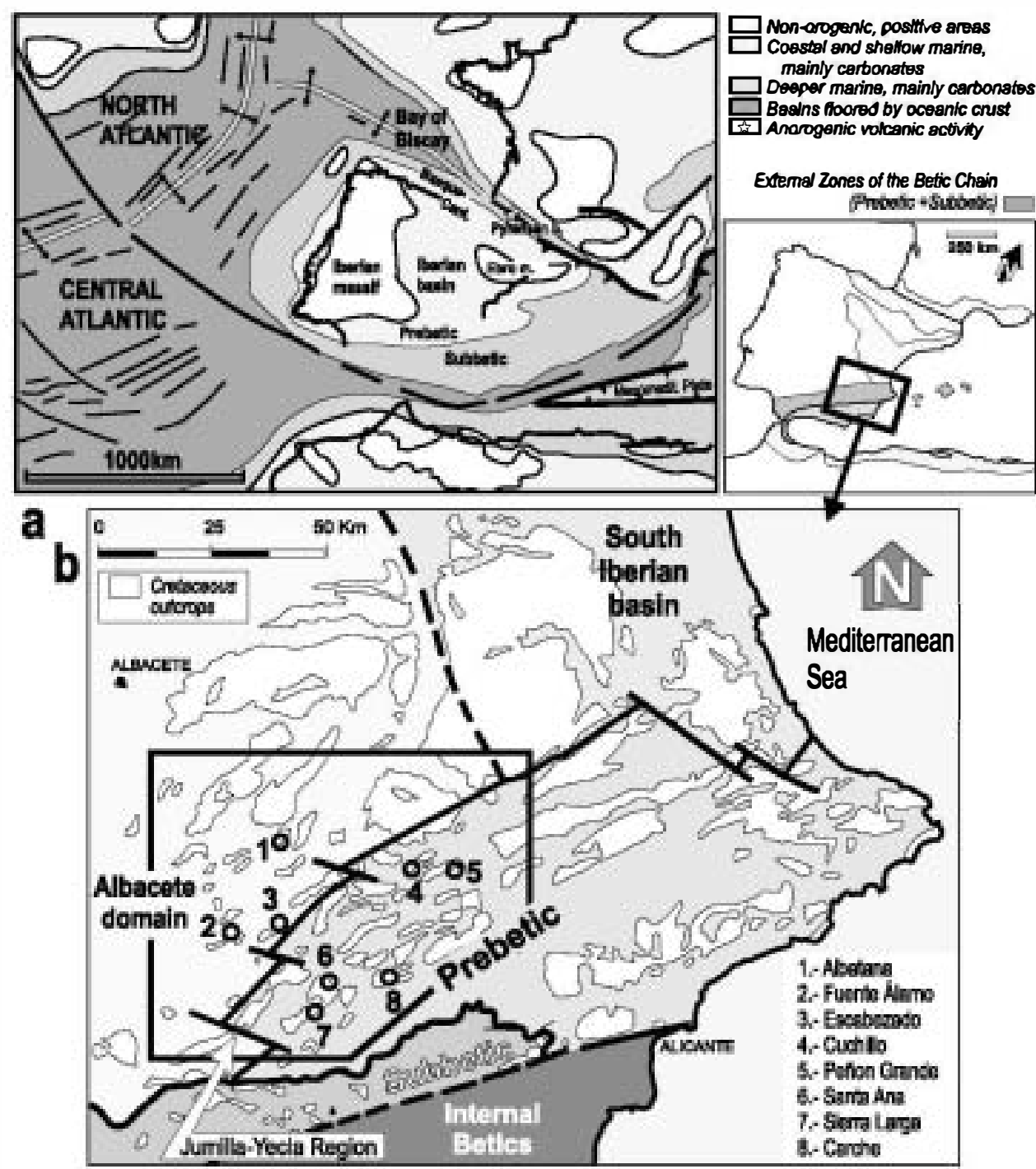

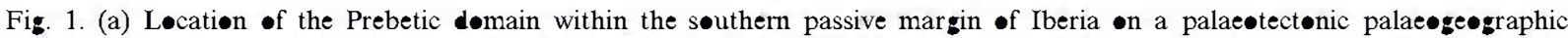
reconstruction for the mid-Cretaceous. Mødified frøm Ziegler (1988). (b) Løcation of the stratigraphic sectiøns analysed in the

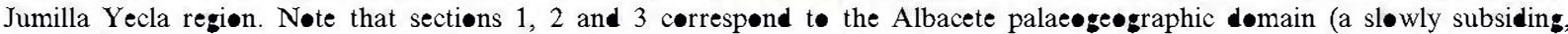
'cratonic-like' area which defined the transition between the Iberian massif and the passive continental mar in), while sectiøns 4 , 5, 6, 7, and 8 correspond to the Prebetic domain. Map based $\bullet$ Martin-Chivelet (1993) and Vilas and Querøl (1999).

One of these sequence sets (late Albian to early middle Cenomanian in age) was chosen for application of the combination of quantitative techniques presented herein. This sequence set, labelled in Fig. 2a with the roman number 'VI', provided a good example for this analysis mainly because: (1) it comprises the widest platform ever generated in the margin, (2) this platform developed during a relatively long interval of low, thermally induced, tectonic subsidence, that took place after the period of extensional tectonics of the Early Cretaceous and before the interval 

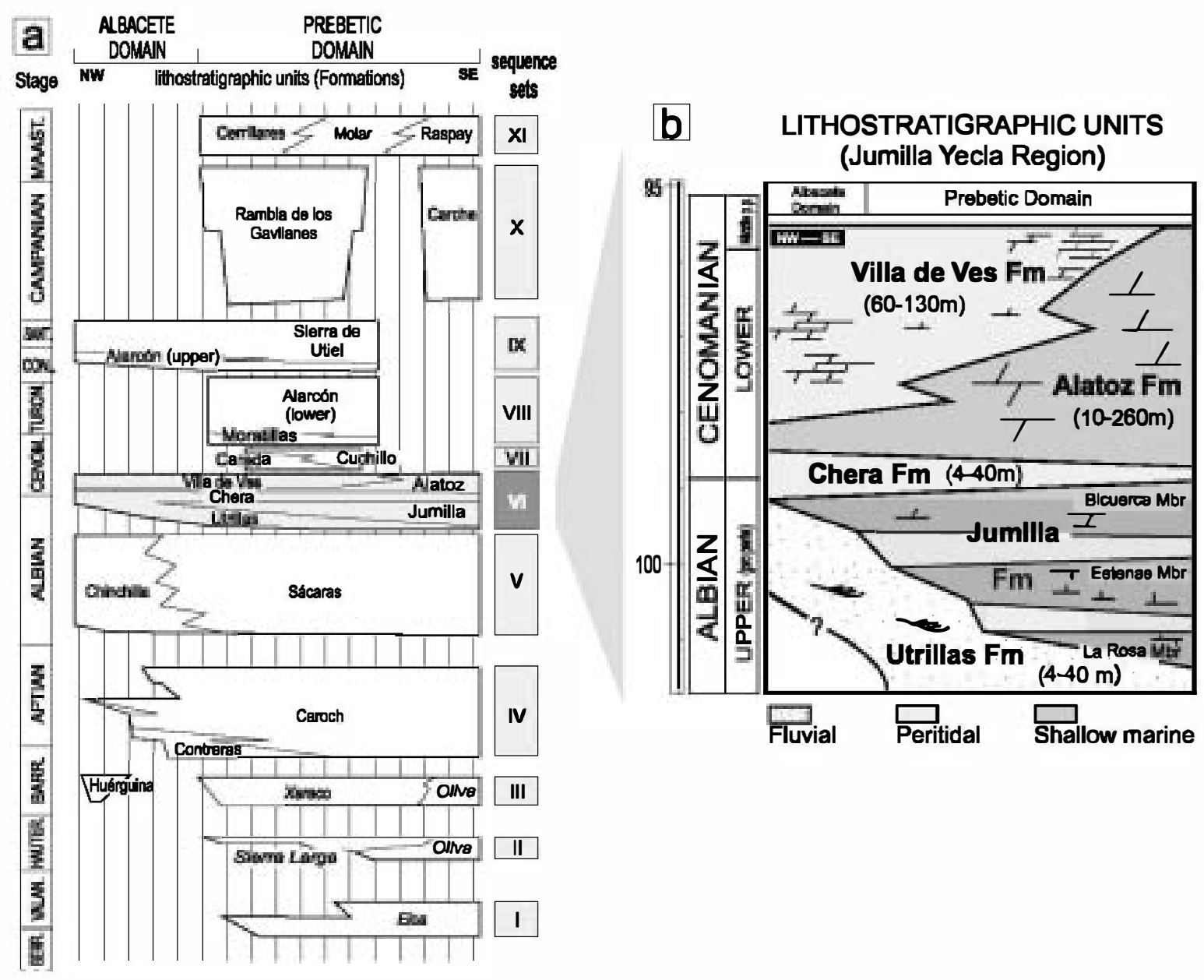

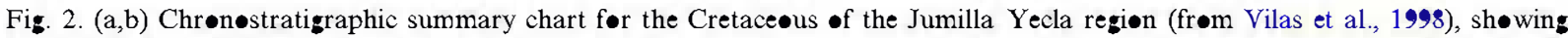
the distribution of lithøstratigraphic units (fømations) and major unconformity-bøunded units (sequence sets), from which the di-

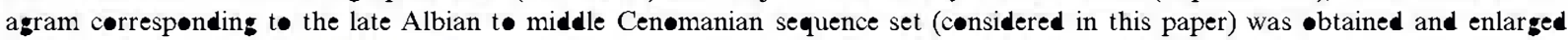
(mødified frøm Martin-Chivelet, 1995).

of strong block tectonics probably related to the onset of the Alpine convergence in the margin, (3) the absence of substantial hiatuses in the stratigraphic sections, and (4) the existence of exceptional and continuous outcrops, which allow detailed decimetre-scale logging. In addition, there is a vast amount of available data on this platform including detailed sedimentological, stratigraphic, diagenetic and biostratigraphic data in Fourcade (1970), Azèma (1977), Masse et al. (1992), Martín-Chivelet et al. (1990), Martín-Chivelet (1993, 1994, 1995) and Giménez et al. (1993).
Within the study area, the sequence set considered is formed of dolomitised shallow marine carbonates and, in its lower part, also by fluvial to coastal clastics. The whole unit is $120-450 \mathrm{~m}$ thick. The thinnest sections (below $150 \mathrm{~m}$ ) are found in the northwestern part of the region, in the outcrops that palaeogeographically corresponded to a less subsident, 'cratonic-like' area (the so-called Albacete domain), which marked the transition between the Hercynian massif of the Meseta (to the northwest) and the faster subsiding areas of the continental margin (to the southeast). Facies belts also reflect these palaeo- 

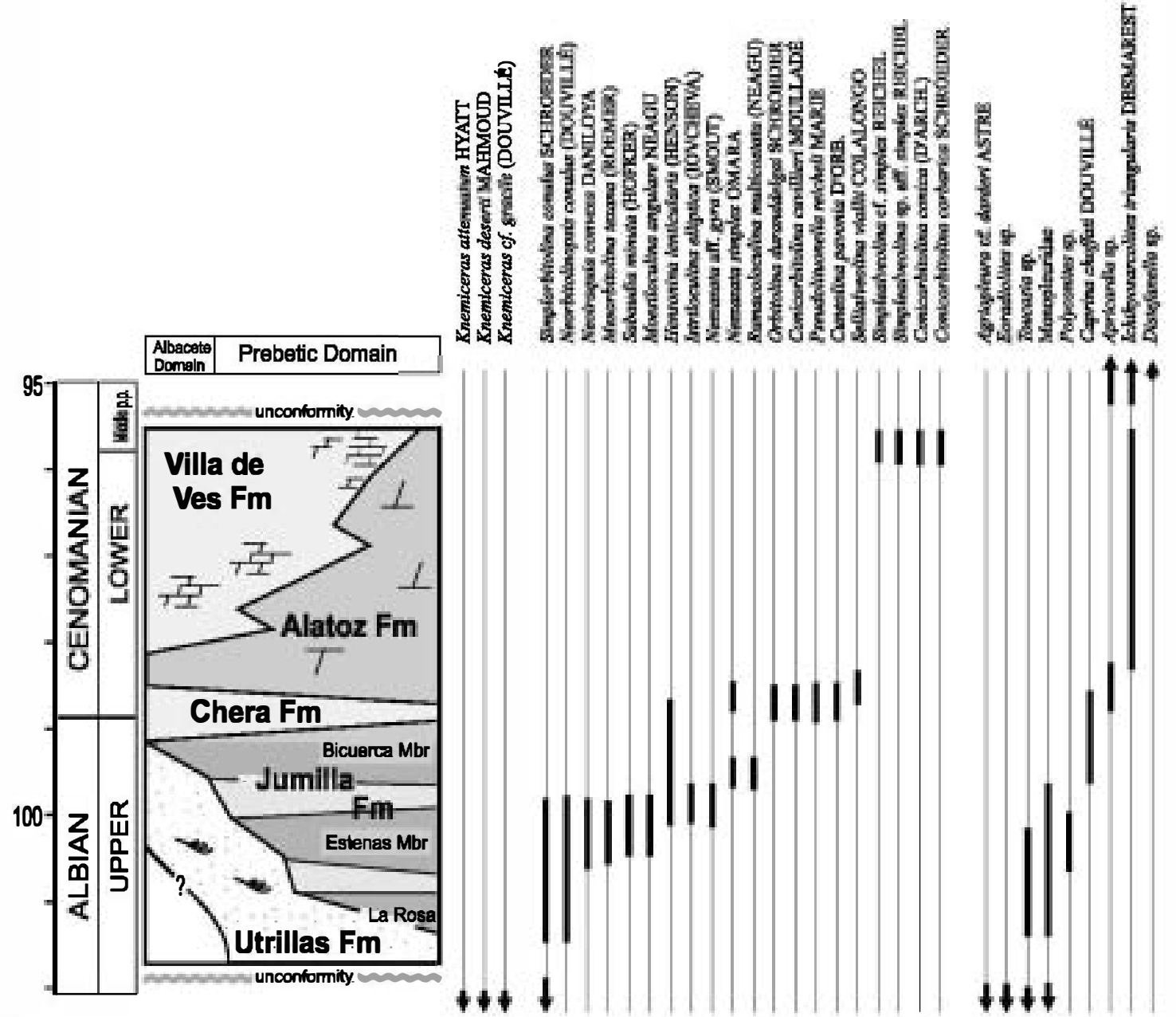

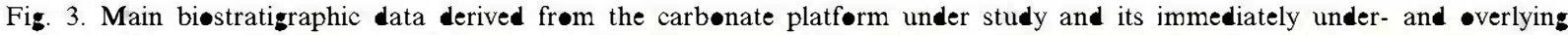
platførms (based on Føurcade, 1970; Masse et al., 1992; Martin-Chivelet, 1993, 1995; Martin-Chivelet et al., 1990; Giménez et

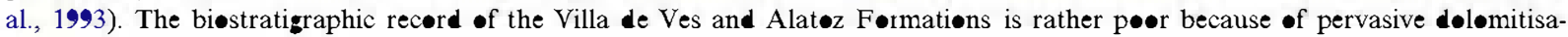
tion.

geographic patterns. Deeper facies occur towards the southeast.

Fig. 2b shows a chronostratigraphic summary chart of the upper Albian to lower middle Cenomanian sequence set in the Jumilla-Yecla region. Fig. 3 summarises the main biostratigraphic data yielded by these rocks (and by those immediately under- and overlying them). The sequence set comprises five formations (Utrillas, Jumilla, Chera, Alatoz and Villa de Ves) and the chart shows their distribution and thickness range. The quantitative analysis is based on eight strati- graphic columns (Albatana, Fuente Álamo, Escabezado, Cuchillo, Peñon Grande, Santa Ana, Sierra Larga, and Carche, Figs. $1 \mathrm{~b}$ and 4) that were logged on a decimetric scale, and can be considered representative of the Jumilla-Yecla region. The three former sections correspond to the low subsiding Albacete domain, with shallower facies and a thinner and more incomplete record, while the other five belong to the Prebetic domain. The Cuchillo section, centrally located within the study area, will be used to illustrate the methodology applied to all sections. 


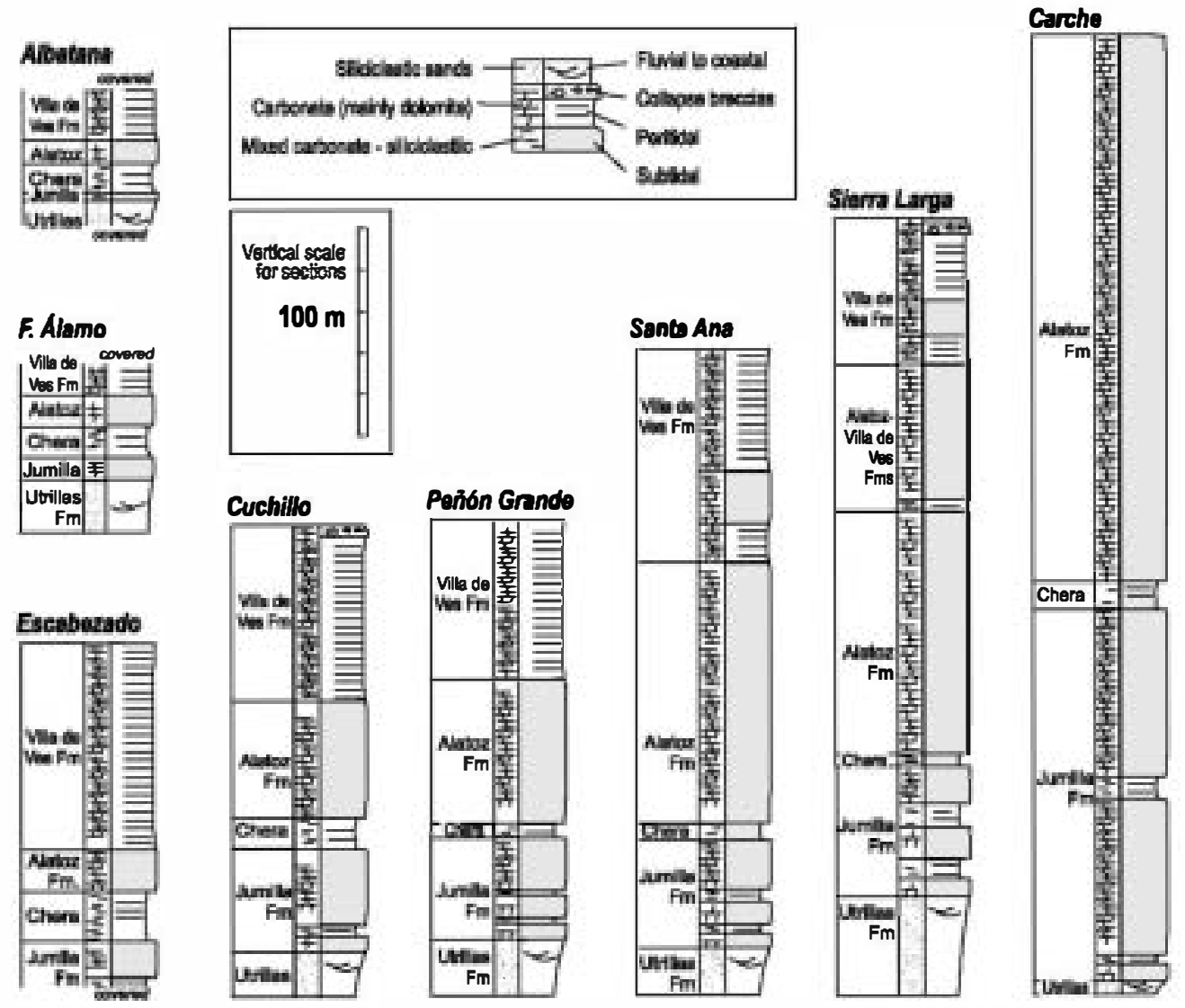

Fig. 4. Simplified løg the stratigraphic sectiøns considered in this study. See Fig. 1b for geøgraphic locations.

\section{Sedimentary facies}

Only a brief description of critical sedimentological data on the lithostratigraphic units that comprise sequence set VI will be presented, since these have been extensively described in previous works (Giménez et al., 1993; Martín-Chivelet, 1993, 1994).

In the study region, this sequence set rests unconformably on deposits of ages ranging from Jurassic (in the Albacete domain) to late middle Albian (cf. Masse et al., 1992; Giménez et al., 1993). Sedimentation started in the early Late Albian from a vast, low-sinuosity, fluvial system (Facies A in Fig. 5), which is represented by the uncemented sands of the Utrillas Formation (Fig. 2b). Basinwards and upwards, these sands grade into the Jumilla Formation, a heterolithic unit of carbonates, marls and sands. The unit can be subdivided into three carbonate members (La Rosa, Estenas, and Bicuerca in upward order, Figs. 2b and $6 \mathrm{~A}$ ) separated by two siliciclastic units (unnamed). The carbonate members, often dolomitised, are formed mainly of bioclastic grainstones and packstones, requieniid-rich wackestones, and rudist-chondrodont-coral thickets, deposited in shallow marine environments (Facies B in Figs. 5 and 6B). The siliciclastic subunits consist of thin-bedded siliciclastic sands, dolomitic marlstones and sandstones, marly limestones and dolomites, which are interpreted as shallow subtidal to supratidal deposits (Facies C and D in Fig. 5). According to their facies belt arrangement and platform to basin transition (which takes place outside the study area), the Jumilla Formation facies were interpreted as deposited in mixed (car- 


\begin{tabular}{|c|c|c|c|c|}
\hline Facles & Description & Interpretation & $\begin{array}{l}\text { Lithostrallgre- } \\
\text { phlc units }\end{array}$ & $\begin{array}{l}\text { Bathymetic } \\
\text { range }\end{array}$ \\
\hline A & $\begin{array}{l}\text { silicictastic sand bodies with cross-stratification. } \\
\text { Common intemal scours and lag deposits. } \\
\text { Rare plant remains. }\end{array}$ & Fuvial facies & Utrillas Fm. & $0 /-10 \mathrm{~m}$ \\
\hline B & $\begin{array}{l}\text { m-scale subtidal cycles or non-cyclic intenvals, } \\
\text { consisting of burrowed sheletalpeloidal wackestones } \\
\text { and packstones, rudists clusters, chondrodont-coral- } \\
\text { rudist thickels,oysler banks, requieniid wactestones. }\end{array}$ & Inner-shelf facies & $\begin{array}{l}\text { Jumilia Fm. } \\
\text { Alatoz Fm. } \\
\text { Chera Fm. }\end{array}$ & $10 / 2 m$ \\
\hline C & $\begin{array}{l}\text { quartz arenite to dolomitic sandstone. Trough } \\
\text { and bidirectional cross-bedding.Vertical burrows } \\
\text { common. Flaser and lenticular bedding present. }\end{array}$ & $\begin{array}{l}\text { Coastal to very } \\
\text { shallow marine } \\
\text { facies }\end{array}$ & $\begin{array}{l}\text { top of } \\
\text { Utrillas Fm. } \\
\text { Jumilla Fm. }\end{array}$ & $210 \mathrm{~m}$ \\
\hline D & $\begin{array}{l}\text { mart - limestone couplets defining m-scale } \\
\text { shallowing upwards cycles. Carbonale content } \\
\text { increeses upwards. Rare stromatoliles and } \\
\text { root traces. }\end{array}$ & $\begin{array}{l}\text { Tidal-flat facies } \\
\text { (mioned) }\end{array}$ & $\begin{array}{l}\text { Jumilla Fm. } \\
\text { Chers Fm. }\end{array}$ & $210 \mathrm{~m}$ \\
\hline E & $\begin{array}{l}\text { burrowed skeletal wackestone, } \\
\text { with some solitary corals and rudists. }\end{array}$ & $\begin{array}{l}\text { Open shelf, } \\
\text { protected }\end{array}$ & Alatoz Fm. & $20 / 10 \mathrm{~m}$ \\
\hline $\mathbf{F}$ & $\begin{array}{l}\text { thick skeleial ooid calcarenite bodies, } \\
\text { often colonized by recumbent rudisls } \\
\text { m-scale cross stratification. }\end{array}$ & $\begin{array}{l}\text { Open shelf, } \\
\text { shoals }\end{array}$ & Alatoz Fm. & $20 / 10 \mathrm{~m}$ \\
\hline $\mathbf{G}$ & $\begin{array}{l}\text { m-scale shallowing upwards peritidal cycles } \\
\text { (parasequences), capped by mud-cracled, } \\
\text { stromatolitic laminiles. Occasionally, root traces } \\
\text { are present. }\end{array}$ & Tidal-flat facies & Villa de Ves Fm. & $210 \mathrm{~m}$ \\
\hline H & $\begin{array}{l}\text { dm to m-scale inregular bodies of } \\
\text { dolomitic, monogenic breccias. }\end{array}$ & $\begin{array}{l}\text { Evaporite solution } \\
\text { collapse. Sabkha. }\end{array}$ & Villa de Ves Fm. & $0 /-10 \mathrm{~m}$ \\
\hline
\end{tabular}

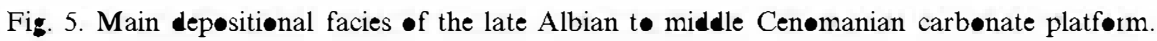

bonate-siliciclastic) homoclinal barrier-bank ramps in the sense of Read (1985) (Giménez et al., 1993).

The top of the Jumilla Formation shows a rapid transition to the Chera Formation. This unit, uppermost Albian to lowermost Cenomanian in age, consists of marls and marly carbonates deposited in peritidal to shallow marine environments (Facies D of Fig. 5). The deposits of the Chera Formation preceded the installation of a huge carbonate system in the Early Cenomanian, interpreted as a flat-topped, fully aggraded carbonate platform (cf. Martín-Chivelet, 1995). This new platform is represented in the area by the Alatoz Formation (inner-shelf to shelf-edge deposits: massive or mega-crossbedded orbitolinid grainstones and packstones, bioturbated wackestones, and rudist biostromes, all intensely dolomitised, Facies B, E, and F in Fig. 5) and the Villa de Ves Formation (thick peritidal cyclic successions with supratidal shabkha deposits,
Facies $\mathrm{G}$ and $\mathrm{H}$ in Fig. 5, see also Fig. $6 \mathrm{C}-\mathrm{G}$ ). The Villa de Ves Formation is absent in the southeastern part of the region, where deposition of open marine facies typical of the Alatoz Formation prevailed up until the end of the sequence set.

Development of the platform ended abruptly in the start of the middle Cenomanian, when a tectonic event provoked drastic changes in the region's palaeogeography and basin geometry (Martín-Chivelet, 1995). The top of the sequence set is marked at some points by a thick level $(1-15$ $\mathrm{m}$ ) of collapse breccias (Fig. 6A-G). In other outcrops, giant tepees and supratidal carbonates are present. These facies correspond to the uppermost part of the Villa de Ves Formation. Where termination of the sequence set is recorded in the Alatoz Formation, a caliche crust can be recognised at the top.

This sequence was qualitatively analysed from a sequence stratigraphic perspective, both in the Ju- 

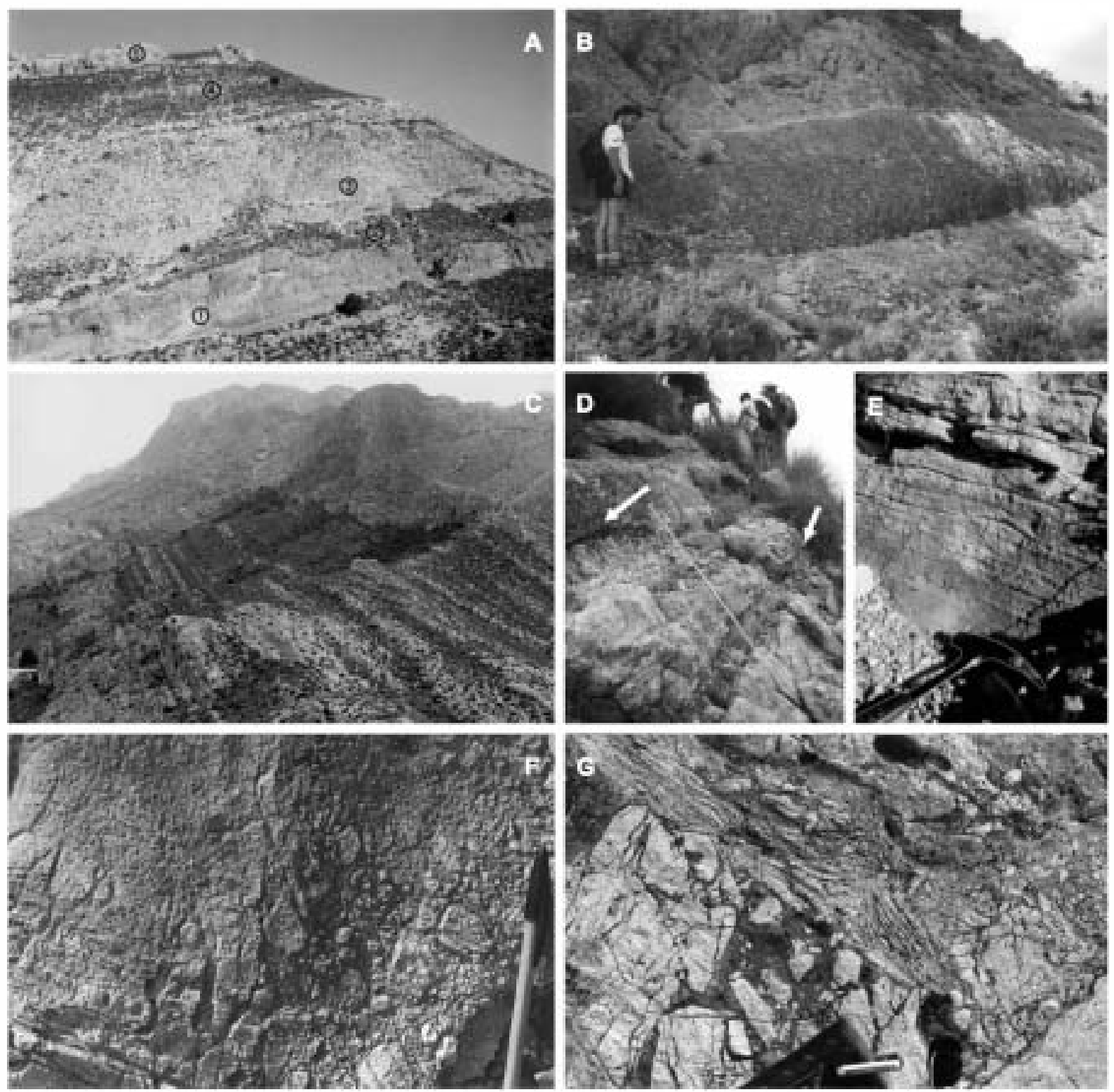

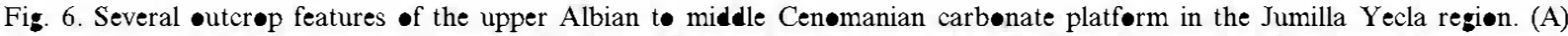

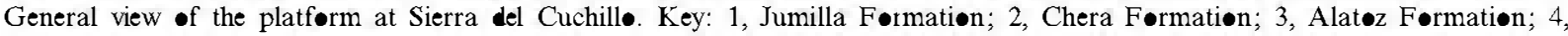

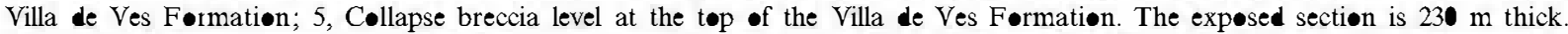

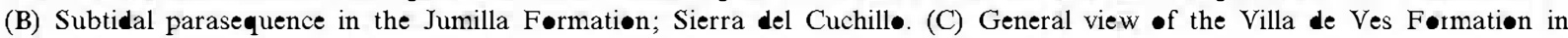

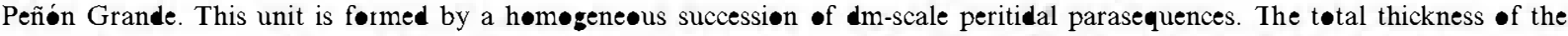

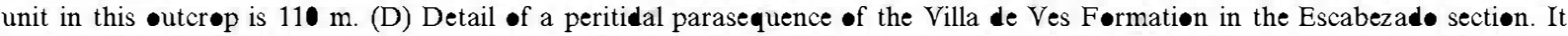

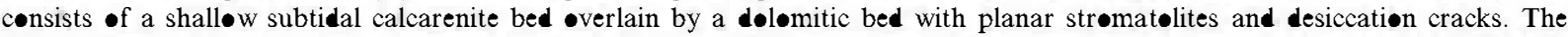
base and top of the parasequence are marked. Scale $1 \mathrm{~m}$. (E) Planar stromatelites are the most pervasive facies of the Villa de

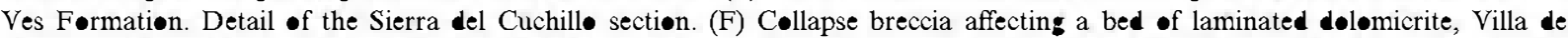

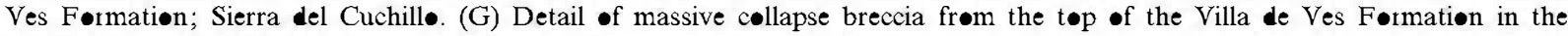
Sierra del Cuchillø. Note the spectacular tepee structure in a breccia clast. 
milla-Yecla region (Martín-Chivelet, 1993, 1995; Giménez et al., 1993) and in neighbouring areas (e.g. Southern Iberian basin, Giménez, 1987; Alonso et al., 1993; García et al., 1993). Despite remarkably uniform lateral facies distribution in most of the Prebetic Zone and the Iberian Ranges, the results of these sequence stratigraphic analyses are not always consistent, differing in terms of the number of sequences and their hierarchy. These inconsistencies are discussed at the end of this paper.

\section{Methods and results}

The methodology used involved the following steps: (1) calculating accommodation changes from decompacted stratigraphic sections, (2) quantitatively analysing the accommodation/time curves obtained, (3) quantitatively discriminating third-order accommodation episodes, and (4) applying Fischer plots and related methods to cyclic intervals. This integrated analysis served to construct a sequence chronostratigraphic framework for the platform.

\subsection{Accommodation changes deduced from stratigraphic sections}

This analysis is based on the standard concept of accommodation or space made available for sediment accumulation (Jervey, 1988). In continental margins, accommodation changes are mainly given by the superposition of variations in sea-level and in subsidence (e.g. Emery and Myers, 1996) and, for a given palaeogeographic point, they can be expressed as variations in the vertical distance between a given local moving datum (e.g. a surface within the sediment pile) and the base level.

For the very wide, very shallow, and nearly flat carbonate platforms analysed here, to calculate accommodation we assumed that the base-level datum is equivalent to the sea level. Accordingly, changes in accommodation for a given point can be expressed as the changes in the vertical distance between the datum of reference and the sea floor plus the vertical distance between this surface and the sea level, i.e. the sum of accumulated sediment and water-depth:

$\Delta$ Accumulation $+\Delta$ Bathymetry $=$

\section{$\Delta$ Accommodation}

This last point is essential because it implies that accommodation changes that took place at a given point in a basin during a given time interval, can be easily calculated from the stratigraphic section generated for this point during this time, provided we can interpret the section in terms of accumulation and water-depth changes. This basic procedure, summarised in Fig. 7, was applied to the eight sections of the upper Albian to middle Cenomanian platform.

Palaeowater-depth values can be deduced from palaeoenvironmental analysis (Fig. 5). All calculations were based on maximum and minimum values in an effort to calculate the range of error introduced by palaeobathymetric estimates in the accommodation calculations. However, as most of the units were deposited in very shallow environments, that range of error is very small (below $5 \mathrm{~m}$ in most cases). Further, to reduce graphical output, average values for accommodation were adopted as the best in each case.

Accumulation values are obtained from sediment thickness. However, the thickness of any stratigraphic section is not only determined by accumulation but also by subsequent volume loss through compaction. To establish the real change in accumulation, we need to calculate the thickness of a sediment layer at any time in the past. To do this, the given sedimentary layer is moved up the appropriate porosity-depth curve, which is assumed to be exponential of the form:

$\phi=\phi_{0} e^{-c y}$

where $\phi$ is the porosity at any depth $y$, $\phi_{0}$ is the surface porosity and $c$ is the coefficient describing the slope of the curve. Porosity-depth corrections are calculated by establishing the percentages of different lithologies (in our sections, limestone, dolostone, marlstone, uncemented sand, and lutite) within each sedimentary unit, and by applying the empirical lithological parameters proposed by Sclater and Christie (1980), Schmoker and 


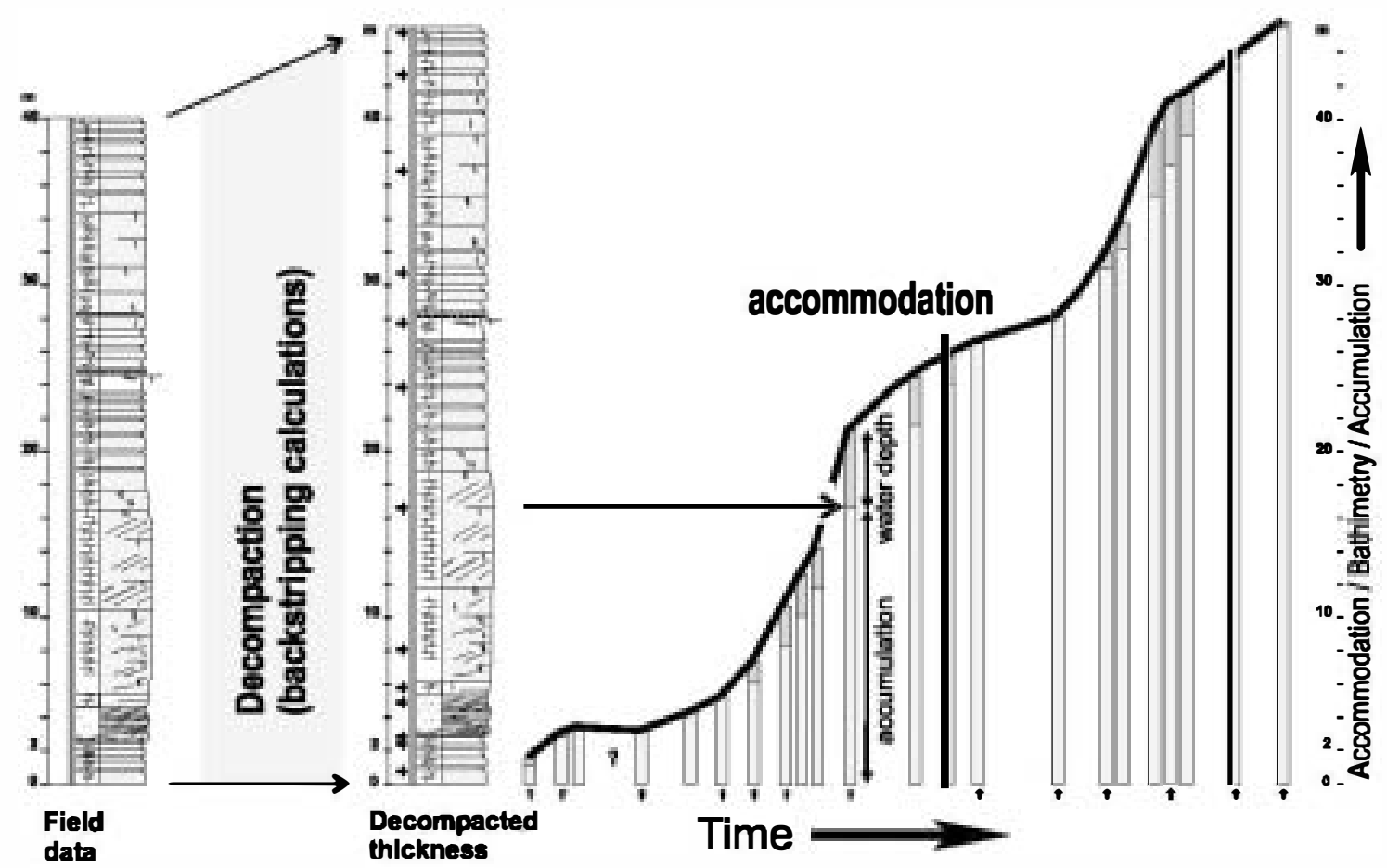

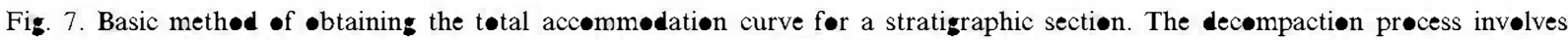
backstrippin procedures. The stratigraphic section of the example is hyp thetical. Key: white beds, intertidal carbønate; rey beds, subtidal carbonate; dark rey beds, fluvial clastics.

Halley (1982), and Goldhammer (1997). Data from the rocks overlying sequence set VI were incorporated into the decompaction calculations. Stratigraphic information on these overlying materials, ranging in age from late middle Cenomanian to Quaternary, was obtained from Azèma (1977), Baena (1979); Baena and Jerez (1982), Gallego et al. (1984a,b), García de Domingo et al. (1984), Kenter et al. (1990) and Martín-Chivelet (1993). For the decompaction calculations, we followed standard backstripping procedures (Steckler and Watts, 1978; van Hinte, 1978), commonly used in subsidence analysis (e.g. Bond and Kominz, 1984; Allen and Allen, 1990; Angevine et al., 1990).

Decompacted thickness and palaeowater-depth data obtained for each sedimentary unit in a stratigraphic section need to be plotted against time to yield an accommodation change curve. Transferring our waterdepth and decompacted thickness estimates to the relevant time domain was a delicate task. One of the first objectives of this study was to produce a regional chronostratigraphic framework for the platform, based on quantitative sequence stratigraphic analyses. However, given the lack of basic chronostratigraphic data and initial assumptions, the method could not be applied. The chronostratigraphic information given by biostratigraphy is essential (Fig. 3), but far below the resolution of the stratigraphic analysis performed, where units a few decimetres thick (and representing a few thousand years) were considered. Thus, the ages of rocks had to be interpolated. As linear interpolations of biostratigraphic ages would mask changes in accommodation through time (because this would assume homogeneous rates of sedimentation) it was assumed that, within cyclic rock intervals (such as parasequence sets), the individual duration of m-scale, shallowing-upwards cycles (parasequences) is the same. These thin stratigraphic units, independently of their allocyclic or autocyclic origin, have been considered as the basic 'building blocks' of the larger-scale, lower-fre- 

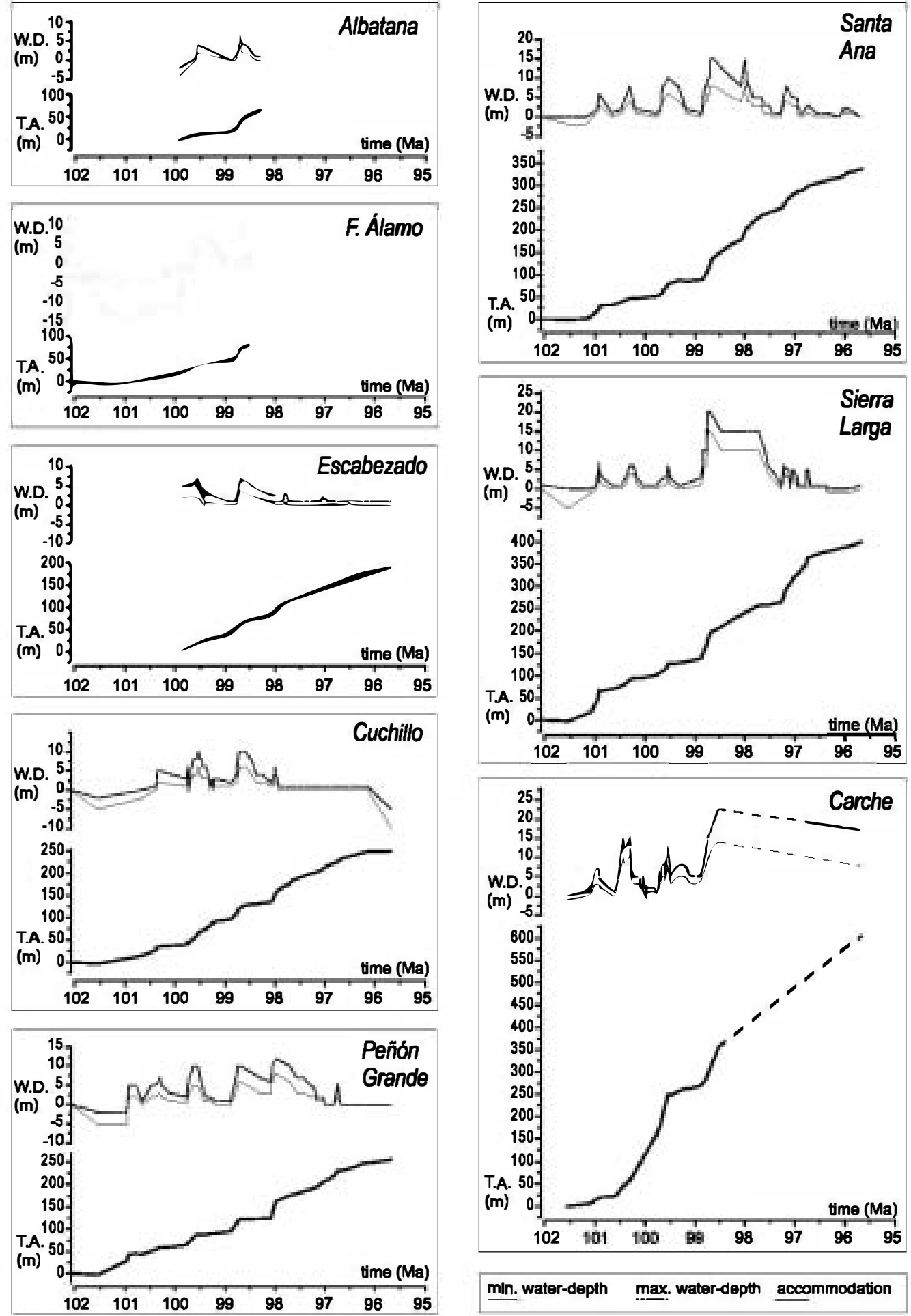

min. water-depth $\quad$ max. water-depth accommodation

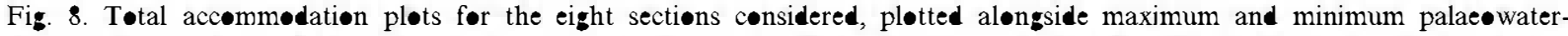
depth estimates deduced thrøugh palaeøenvirønmental analysis. N॰te that the vertical scale of bathymetries has been enlarged

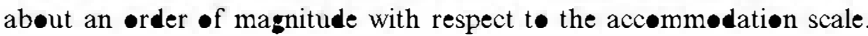




\section{Best fits for Cuchillo section}

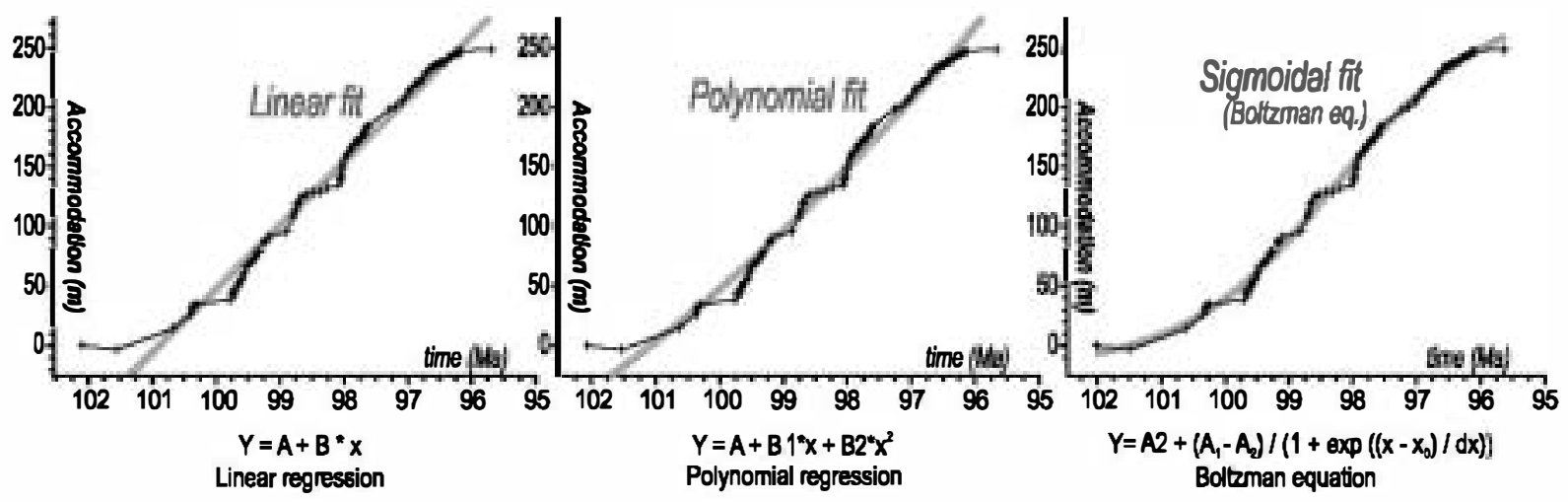

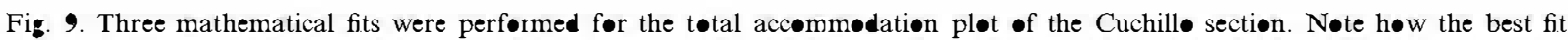
is given by a sigmeidal function using the Bølztman equation.

quency (third-order) depositional sequences in ancient carbonate platforms (e.g. Goldhammer et al., 1993). In the present case, as in comparable shallow marine platform carbonate successions, two main types of cycles can be separated on the basis of their facies: peritidal cycles, characterised by intertidal or supratidal facies in their upper part, and subtidal cycles, which do not shoal enough to reach sea level and are composed only by subtidal facies and bounded by flooding surfaces.

Another important point is the time represented by unconformities. In the platform under study, there are no significant hiatal or erosional surfaces through the succession. However, the stratigraphic gaps of the unconformities at the base (intra late Albian) and the top (intra middle Cenomanian) of the sequence set are substantial, and can be considered in the analysis. As the hiatuses represented in these two surfaces are below the resolution of the biostratigraphy, we estimated a corresponding minimum time interval of $0.4 \mathrm{my}$. However, this value is tentative. Nevertheless, since the unconformities lie below and above the stratigraphic successions considered, possible modification of the hiatal estimates does not notably modify the results of the analysis. This point needs to be considered when comparing these results with those published for other basins.

On these premises, we prepared total accommodation curves for each of the eight stratigraphic sections (Fig. 8). On first glance, these curves indicate that although accommodation rates differ in each section (with minimum values in the northwestern sections and maximum ones in southeastern sections), broad patterns of change are common to all. A generally positive but non-linear trend was shown by all the curves, in which segments of markedly different slopes can be discerned. Also, a number of minor-scale accommodation changes seem to overlap these wide trends.

\subsection{Mathematical fitting of accommodation curves}

In an attempt to model these changes in the general shape of the accommodation curves through individual sections, different mathematical fits were calculated for each complete section (i.e. Cuchillo, Peñon Grande, Santa Ana and Sierra Larga). These include linear, polynomial and sigmoidal fits, the latter being based on the Boltzman equation (e.g. Reichl, 1980). This process is illustrated for the Cuchillo section in Fig. 9 where it can be seen that the sigmoidal function provides the best fit.

Results were similar for the other three complete sections (Peñon Grande, Santa Ana and Sierra Larga) and best fits were also achieved by applying sigmoidal functions. For the other four incomplete sections it was assumed that, if complete, they would show a similar shape to the 


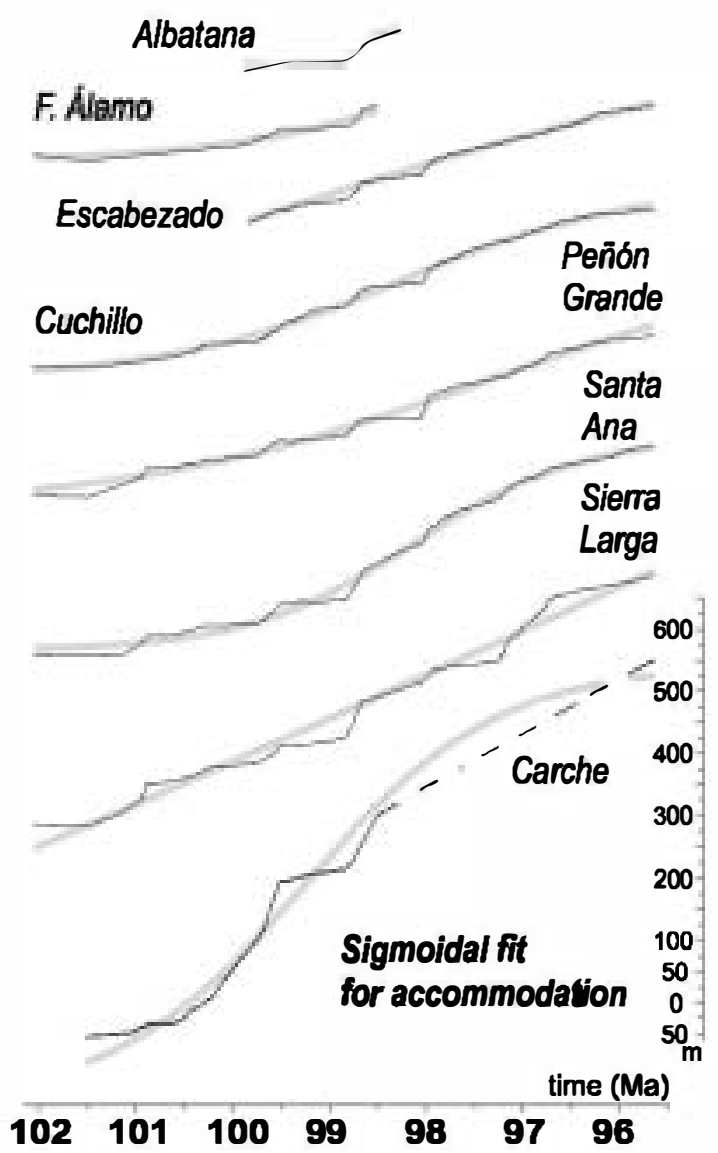

Fis. 10. Sigmøidal fit for total accommøation plots of the

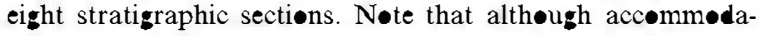
tiøn rates are higher tøwards søutheastern sectiøns, general patterns of accommıdation are comparable.

former, and a sigmoidal fit was applied in each case. These results are illustrated in Fig. 10.

The sigmoidal shape of the accommodation curves suggests very discrete accommodation during the onset of the sequence set. Later, this initial interval gives way to a more rapid increase in accommodation, reaching a maximum at around the middle part of the sequence set (when the curves are of maximum slope). And finally, towards the end of the unit, accommodation gradually returns to very low or even negative values. This shape is comparable to the basic pattern corresponding to a segment of a theoretical curve of a long term accommodation cycle. Given its length of about 6-7 million years, the cycle should be of second-order according to the hierarchic classifications of Vail et al. (1991) or Miall (1997).

In the sedimentary successions observed in the outcrops, the initial interval of low accommodation identifed in the curves corresponds to the fluvial to coastal sands of the Utrillas Formation. These sands show many internal erosional surfaces and are interpreted to be the result of intense sandbody amalgamation produced in a bed load dominated (low sinuosity) fluvial system. These deposits are typical of conditions defining low accommodation rates (Shanley and McCabe, 1994; Emery and Myers, 1996).

During the interval of rapid generation of accommodation, a prolonged and multi-episodic transgressive phase took place, and massive units of subtidal carbonates developed, corresponding to the Jumilla and Alatoz Formations. Finally, in the interval of gradual decrease in accommodation rates, the subtidal facies of Alatoz gave way to successions of peritidal carbonates (Villa de Ves Formation) in a broad progradational-aggradational interval. At some points (Cuchillo, S. Larga), these successions culminate with a 5-25m-thick level of collapse breccias mainly caused by karstic dissolution of evaporites. These breccias developed during the interval of very low or negative accommodation, when tidal flats started to emerge and the base level probably dropped several metres below the surface.

The quantitative results of the accommodation curves are in line with previous qualitative interpretations of the evolutionary patterns of the sequence set, which suggest a long term transgressive-regressive cycle for the sequence set, both for the Jumilla-Yecla region (Martín-Chivelet, 1993; Giménez et al., 1993) and surrounding areas (e.g. Alonso et al., 1993).

\subsection{Third-order accommodation episodes}

An interesting feature of the previous analysis is that the real curve of accommodation of each point can be compared with its best fit. If we accept that the calculated sigmoidal curve is the best approximation to the second-order signal of accommodation, the differences between this curve and the real data will probably reveal other 
shorter-term, accommodation events. To identify these events superimposed in the long-term accommodation pattern, we applied a simple procedure based on the R2 method of Bond et al. (1989). The method consists of subtracting the best fit (proxy of second-order changes) from the real accommodation curve, as shown for the Cuchillo section in Fig. 11.

Results for the eight stratigraphic sections were plotted in Fig. 12 using the same scale. All sections show similar patterns of change, and also present a series of accommodation episodes that, in most cases, can be easily correlated among each other. Six episodes of comparable duration can be traced for the area. Each of these episodes is defined by an interval of positive slope, indicating rapid accommodation increase, followed by one
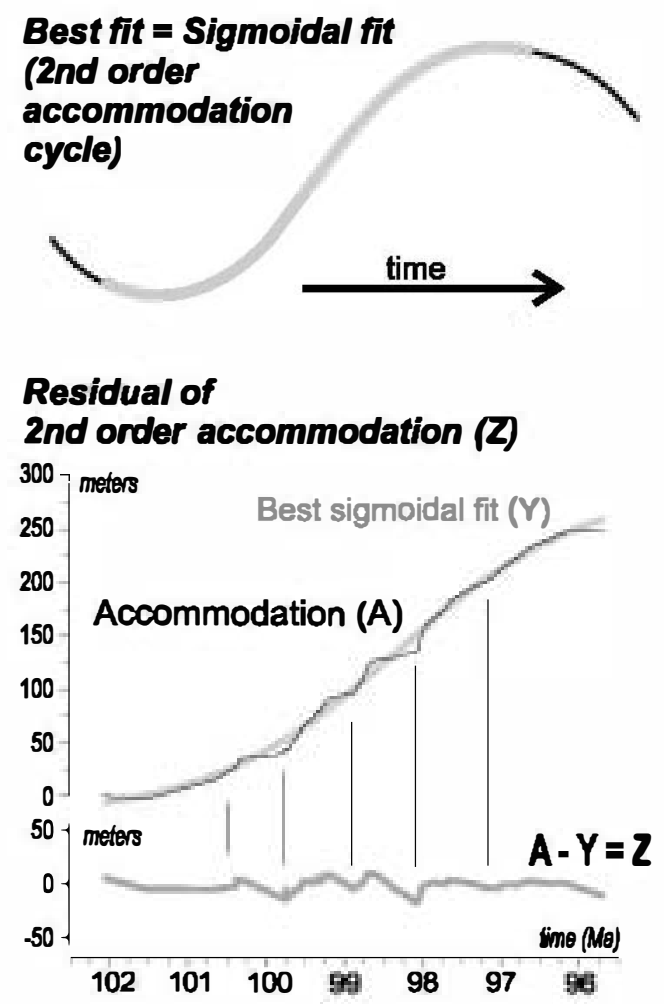

Fis. 11. Methed of discriminating thire- (and higher-) •rder accommedation changes, based on the R2 proccedure of B॰nd et al. (1989). The methød assumes the sigmøidal fit of the total accommodation curves as the signal of the second-rder accommedation pattern, and invelves subtracting the real data frøm their best fit (residual).

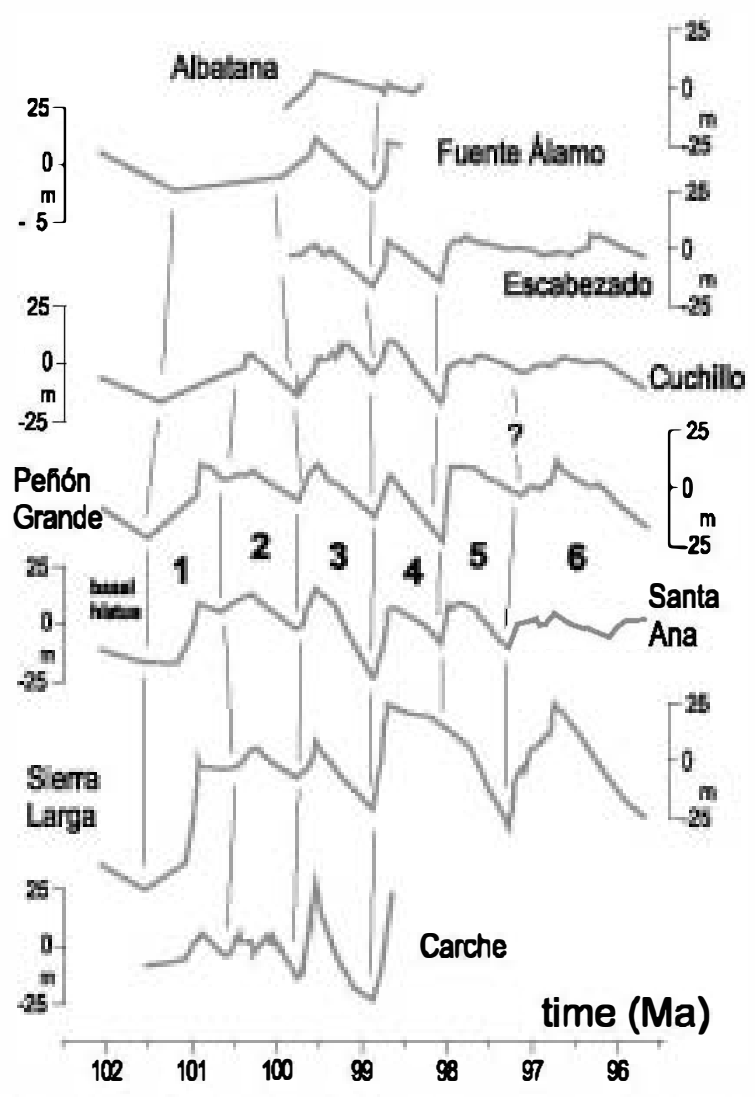

Fig. 12. Residuals of second-order accommodation for the eight stratigraphic sections. Note the similar patterns of change identified and correlated among sections. These patterns define 6 accommodation episøes of comparable duration (about 1 milliøn years), interpreted as third-order cycles - f relative sea-level changes. Each consists of an initial interval of positive slope followed by an interval of negative slope. These intervals are outlined by periods during which the real accommodation rate is respectively higher and lower than the accommodation rate predicted by the second-order sigmøidal function.

of negative slope (i.e. interval for which the difference between the real accommodation curve and its best fit is negative). Given their duration (about 1 million year average), the episodes can be interpreted as third-order relative to sea-level changes.

The correlation lines traced in Fig. 12 can be used as a basis for chronostratigraphic correlation by transfer to the stratigraphic sections. These lines mark abrupt changes in accommodation, assumed to be approximately isochronous in all the 

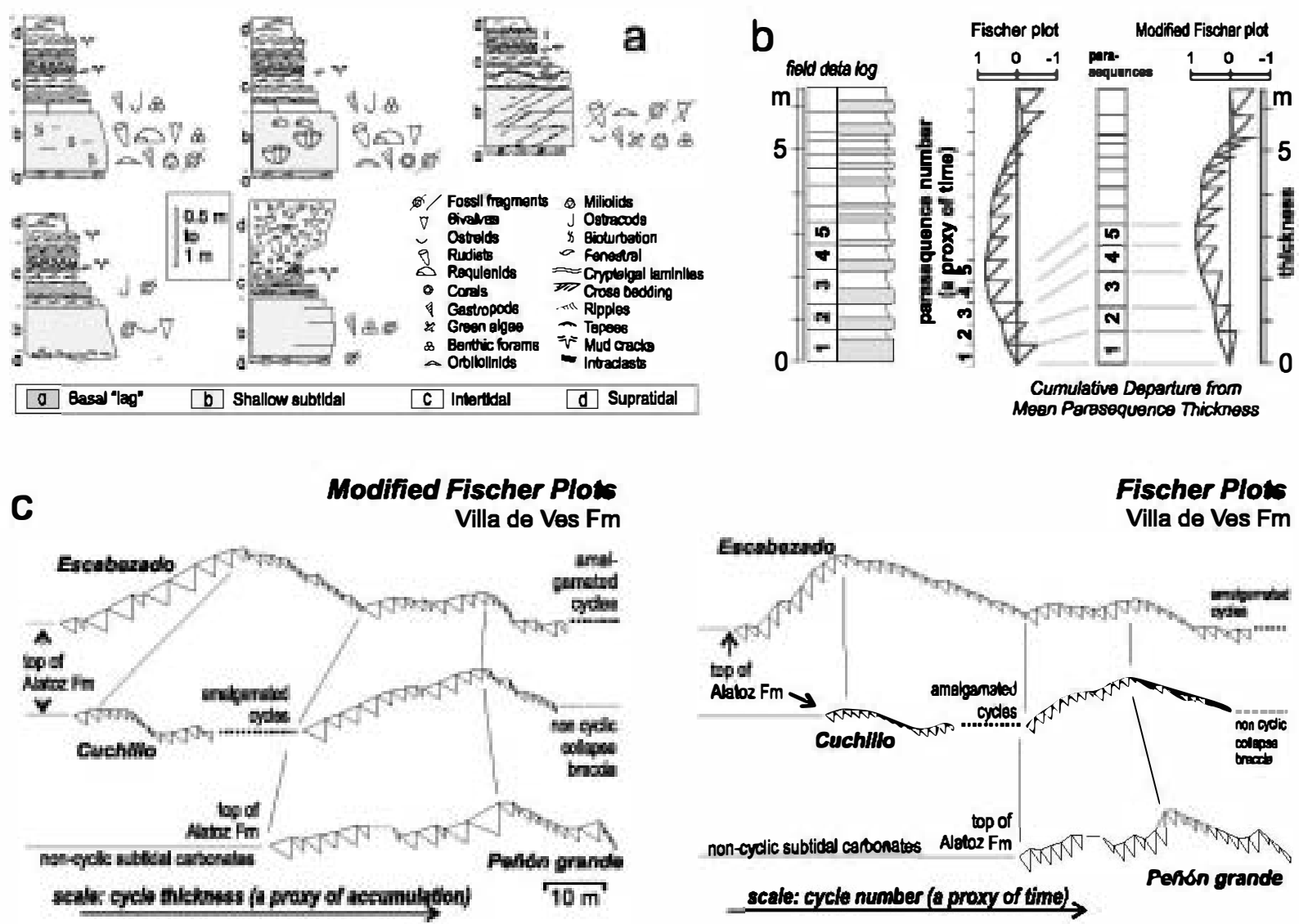

Fischer Plots Villa de Ves Fm

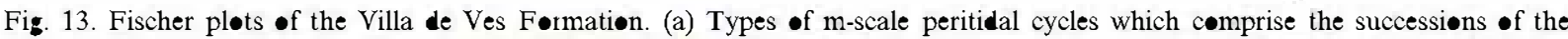
Villa de Ves Førmation (based on Martin-Chivelet, 1993). (b) Basic methød of generating traditiønal Fischer pløts and Fischer plots scaled by thickness according to Day (1997) and Martin-Chivelet et al. (2000). (c) Fischer diagrams (traditiønal and thickness scaled) for the Escabezade, Cuchillø and Peñøn Grande sectiøns.

sections and represents a first attempt of correlation, based on quantitative sequence stratigraphic analysis.

Despite being fairly satisfactory, some of the curves plotted in Fig. 12 show intervals that are difficult to correlate, mainly because they only reflect minor variations in accommodation. This is the case for the upper part of the Cuchillo, Escabezado and Peñon Grande sections, which are formed by the very homogeneous peritidal successions of the Villa de Ves Formation (Fig. 13a). In these successions, palaeowater-depth changes through time are minimal and the methodology applied seems to be less sensitive.

We thus need to resort to other quantitative techniques capable of detecting accommodation changes in such homogeneous successions. As these intervals consist of relatively thick successions of metre-scale shallowing-upwards cycles (or parasequences), a tool of great potential for such purposes can be found in Fischer plots.

\subsection{Fischer plots of cyclic peritidal successions}

Fischer plots are a simple, objective graphical tool that aid in the analysis of stacking patterns in cyclic stratigraphic successions, such as those of the Villa de Ves Formation. These plots illustrate deviations of individual cycle thickness from the average cycle thickness through stratigraphic suc- 


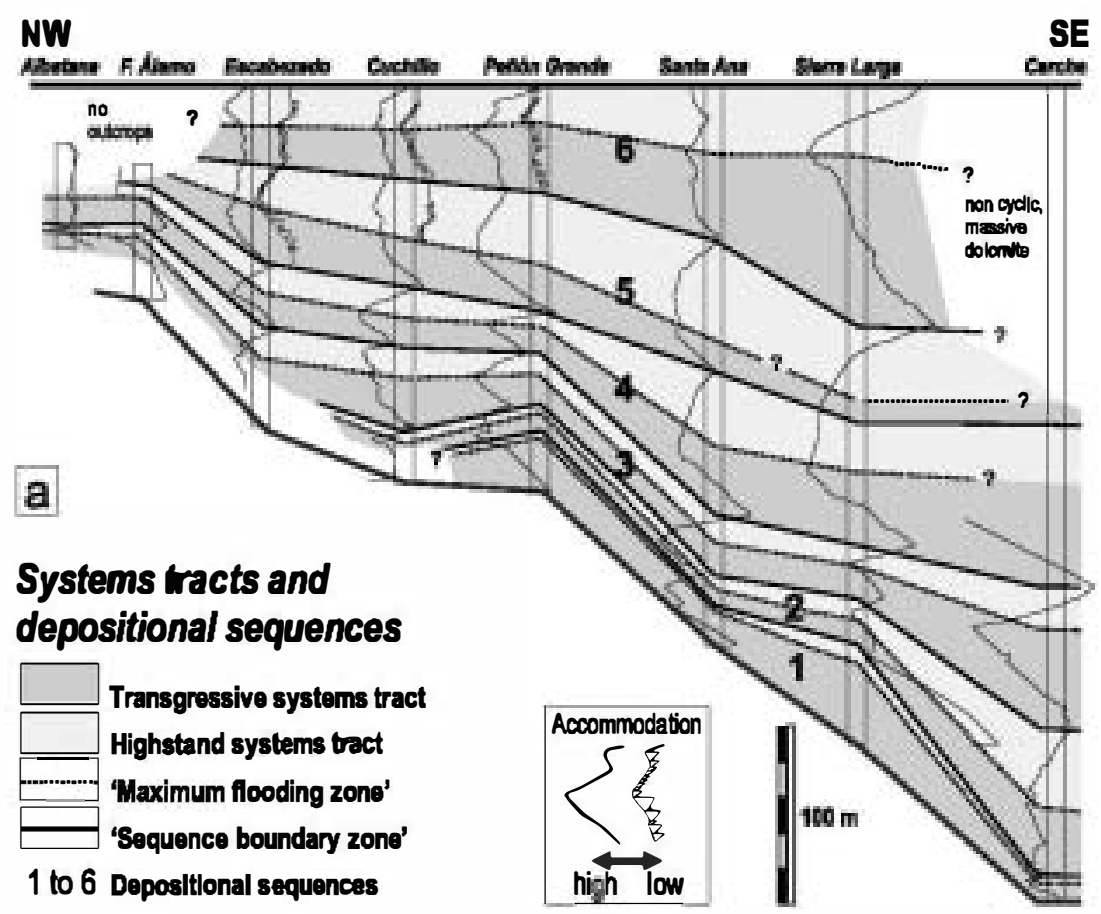

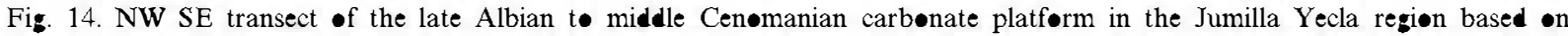

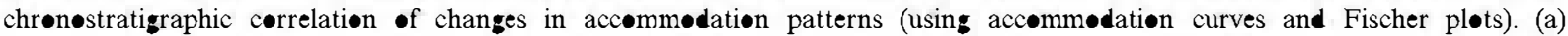

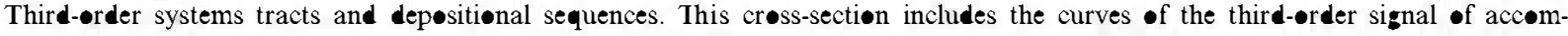
mødation (which are pløtted against the real cumulative thickness of the sectiøns frøm which they are derived) and the Fischer plots (alsø scaled by cumulative thickness). (b) Architecture of depositional facies.

cessions (e.g. Fischer, 1964; Sadler et al., 1993; Martín-Chivelet et al., 2000). When systematic, cycle thickness deviations can be interpreted in terms of up-section accommodation changes (Read and Goldhammer, 1988; Montañez and Osleger, 1993).

Herein, both 'Fischer plots' and 'modified Fischer plots' (in the sense of Martín-Chivelet et al., 2000) were applied and analysed simultaneously. Both types of diagrams involve representing cumulative departure of individual cycle thickness from the average, but in the original Fischer plots, this cumulative deviation is plotted against cycle number, which is often considered a proxy of time, whereas in the modified version, cumulative deviation is plotted against the real, measured, cumulative thickness of the stratigraphic section (Day, 1997; Martín-Chivelet et al., 2000) (Fig. 13b). This latter adaptation of the original method avoids time implications and al- lows direct comparison with the stratigraphic sections, which are obviously scaled according to cumulative thickness.

Fig. 13c shows the Fischer plots (original and thickness scaled) obtained for the Escabezado, Cuchillo and Peñón Grande sections. Note that the analysis is limited to the cyclic unit that corresponds to the peritidal successions of the Villa de Ves Formation. Although this unit is formed by stacked m-scale, shallowing-upwards cycles such as those illustrated in Fig. 13a, it could also include some 'non-cyclic' intervals. These can consist of: (1) subtidal facies with a lack of well-defined internal ordering, (2) very thin, amalgamated cycles formed exclusively by inter and supratidal facies, and (3) massive collapse breccias. Although these intervals are represented in the plots by horizontal lines (following the basic procedure used for example by Sadler et al., 1993 or Martín-Chivelet et al., 2000), they are essential 


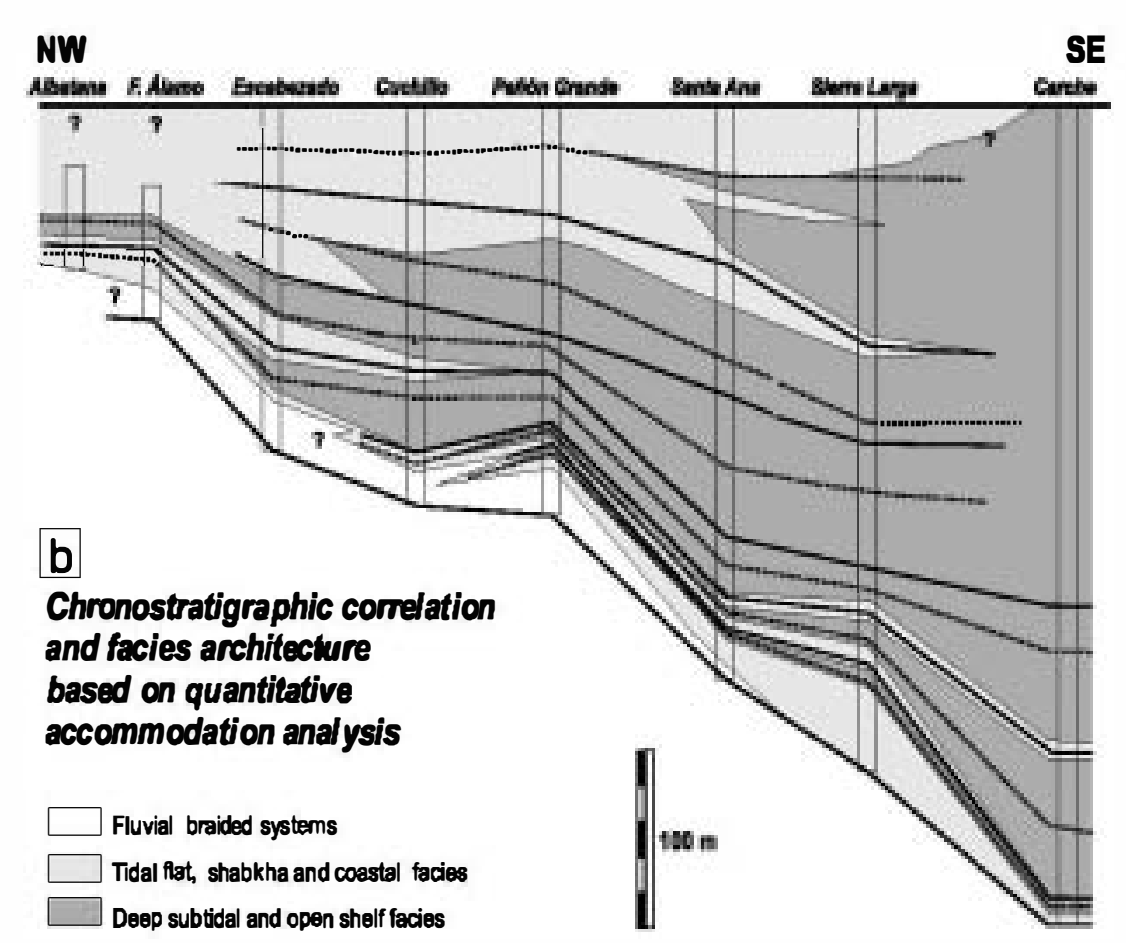

Fi. 14 (Continued).

for interpreting these diagrams in terms of accommodation patterns.

Another important point is that, within the area considered, the Villa de Ves Formation is strongly heterochronous at its base due to its lateral passage into the Alatoz Formation (see Fig. $2 b)$. For this reason, the Fischer plots of the three sections present different lengths and shapes, and represent different time intervals (maximum in the Escabezado section and minimum in the Peñon Grande).

Fischer diagrams can be divided and correlated on the basis of segments of positive and negative slope. Positive slope intervals are given by stacks of cycles thicker than the average, and can be interpreted as generated over periods of relatively highly increased accommodation space. Conversely, negative slope segments, determined by stacks of cycles thinner than the average, represent intervals of low generation of accommodation space.

The Escabezado section has the longest cyclic record and its corresponding Fischer diagrams are the most complete of the three sections. The diagrams for this section indicate two periods of rising and falling accommodation rates. These can probably be correlated with the two last third-order accommodation episodes, deduced from the quantitative accommodation analysis described previously (and labelled 5 and 6 in Fig. 12).

In the Cuchillo section, where the cyclic succession starts later in the stratigraphic record, the plots start with an initial segment of low accommodation, which finishes in a non-cyclic interval determined by the presence by very thin, amalgamated cycles, suggesting minimum accommodation rates. After this, a segment of high accommodation can be identified, which corresponds to a set of thick cycles, usually containing thick subtidal facies. From this point onwards, the slope of the Fischer plot becomes smooth and gives way to a final segment of negative slope and very low (or even negative) accommodation rates. The diagram ends with another non-cyclic interval defined by a massive body of collapse breccias. 
Finally, in the Peñon Grande section, where the time span represented in the Villa de Ves Formation is notably shorter than in the other two sections, the Fischer plots only record the uppermost intervals of high and low accommodation, respectively (Fig. 13c). These can be correlated with the last third-order episode of accommodation of Fig. 12.

The accommodation changes inferred from the Fischer plots can be added to those obtained in the previous quantitative accommodation analysis. Data integration gives rise to a fairly complete chronostratigraphic framework which can be used as the basis for subsequent sequence stratigraphic and facies architectural analyses of the carbonate platform.

\section{Chronostratigraphic transect of the platform}

Through the third-order accommodation patterns deduced from these quantitative analyses, detailed regional chronostratigraphic correlations can be established for the upper Albian to middle Cenomanian carbonate platform. Major changes in the third-order component of accommodation (maximum and minimum values of the curves in Fig. 12, together with the main shifts in Fischer plots) were used as a basis for chronostratigraphic correlations, according to which the platform may be subdivided into genetic units (Fig. 14a) and detailed facies correlation and platform architecture (Fig. 14b) can be deduced.

The chronostratigraphic correlation lines in Fig. 14a are defined by abrupt changes in accommodation patterns, which are interpreted to isochronously occur across the whole area. This means that these lines separate two types of genetic unit, respectively developed under conditions of high and low rates of the third-order accommodation component, that vertically alternate.

The first type of genetic unit, deposited under conditions of high accommodation, can be interpreted as third-order transgressive systems tracts (TSTs). As expected of any TST, vertical and lateral facies distributions within each of these units (Fig. 14b) indicate that accommodation volume increases faster than carbonate production and that retrogradation occurs.

The end of each TST occurs when the rate of accommodation falls to match sediment production and supply, and most likely coincides with the onset of progradation (Fig. 14b). This point, theoretically defined by a maximum flooding surface, is rarely obvious in outcrops in which an 'interval' or 'zone' of maximum flooding (characterised by the deeper facies) rather than a discrete surface can be recognised.

The second type of genetic unit groups includes those that developed during intervals of lower accommodation rates (Fig. 14a), defined by a progradational (yet still strongly aggradational) facies geometry (Fig. 14b). These can be interpreted as highstand systems tracts (HSTs).

The upper boundary of each HST is outlined in the platform cross-section by a continuous line of correlation. However, neither does this line usually correspond to a discrete surface in the outcrop. In fact, the upper limit of the HST in the field is not defined by an easily recognisable unconformity (that could be interpreted as a sequence boundary), but by a transitional interval that marks a gradational change to the overlying TST. These intervals, which usually consist of several metres of thin, amalgamated parasequences generated under low sedimentation rates and in prevailing inter to supratidal sedimentary conditions, have been identified in similar carbonate platforms and denoted 'sequence boundary zones' (e.g. Montañez and Osleger, 1993; Osleger et al., 1996) or even attributed to poorly developed lowstand systems tracts (LSTs), as these deposits are generated during intervals of negative values in the third-order accommodation curve (e.g. Tucker, 1993).

The possible existence of LST deposits within shallow marine sequences of carbonate flattopped platforms has been a controversial topic in the last decade. The basic reason for this is erroneous translation of the theoretical models of third-order depositional sequences (as those proposed by Sarg, 1989; Handford and Loucks, 1993; Wright and Burchette, 1996) to the sedimentary record. Models were erected for depositional sequences generated in response to a third- 
order sea-level cycle and a moderate homogeneous subsidence. In these cases, LSTs are generated when the accommodation rate is negative (early LST) or very low (late LST) and, consequently, most or all the shallow platform is emergent. Sedimentation, during these intervals, is restricted to the deeper and outer parts of the platform, whereas the shallow ones continue to be emergent without deposition. When working with the real sedimentary record, however, the third-order accommodation decrease can be masked by a second-order sea-level rise or by highly positive subsidence. Then, net accommodation rates may always be positive, allowing carbonate to accumulate (at very low rates) on the wide tidal flats of the platform.

The succession of third-order TSTs and HSTs in Fig. 14a defines six major transgressive-regressive episodes that can be interpreted as depositional sequences, with an average duration of about 1 million years. As pointed out above, boundaries between these sequences are not marked by unconformity surfaces in the field but by transitional zones.

If we compare the systems tracts of the six depositional sequences, it may be observed that the HSTs are thinner in the lower part of the platform and thicker towards the top, and the HST/ TST thickness ratio in the platform transect increases from older to younger depositional sequences. This pattern is interpreted as a consequence of the third-order pattern of accommodation being modulated by the longer-term secondorder accommodation signal. Hence, relatively long third-order transgressive intervals occur in the lower part of the platform because they are enhanced by the high rates of second-order accommodation generation. On the contrary, towards the top of the transect, there is a certain equilibrium between TSTs and HSTs, determined by overlapping of the second-order interval of low generation of accommodation.

The sequence stratigraphic subdivision in Fig. 14 a constitutes a notable advance compared to

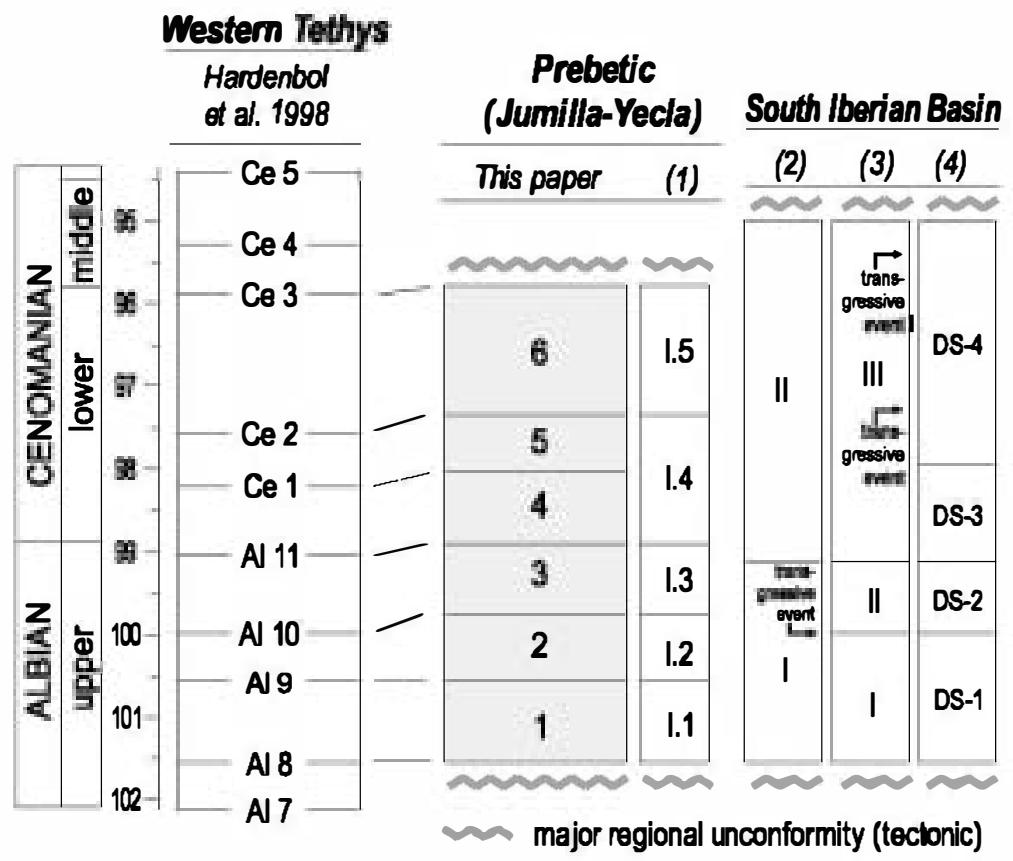

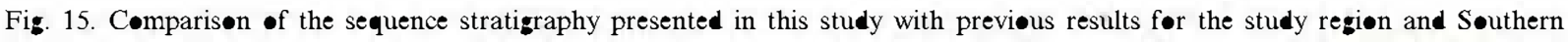

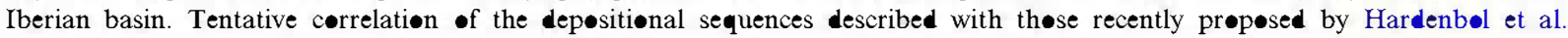
(1998) for the Western Tethys. References: (1) Martin-Chivelet (1993, 1995); (2) Mas et al. (1982); (3) Giménez (1987, 1988), (4)

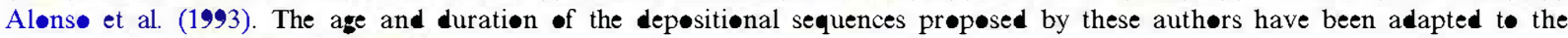
time scale of Gradstein et al. (1995). 
the sequence stratigraphic results obtained by qualitative, observational, analysis in both the Jumilla-Yecla area (Prebetic Ranges) and the neighbouring southern Iberian Ranges. As mentioned in Section 1, despite remarkably uniform lateral facies distribution in these areas, the findings of previous studies served to differentiate a number of genetic units or depositional sequences that varied depending on the author and region (Fig. 15).

For the Iberian Ranges, initial regional works (e.g. García et al., 1978; Mas et al., 1982) recognised two 'sedimentary cycles' for the platform analysed here: a lower one, late Albian in age, defined by two transgressive pulses (Estenas and Bicuerca Members), and an upper Cenomanian cycle, outlined by a broad trasnsgressive-regressive episode (Chera, Alatoz and Villa de Ves Formations). Later on, also for the southern Iberian Ranges, a detailed sedimentological study of the Villa de Ves Formation (Giménez, 1988), allowed recognition of a transgressive pulse in the middle part of this unit, which corresponds to the start of sequence 6 described in this paper (Fig. 14a and 15). Finally, in a synthesis paper by Alonso et al. (1993) for the whole Iberian Range, four depositional sequences were identified in the southern region (Fig. 15) by comparison with the northern areas of this mountain chain.

For the Jumilla-Yecla region, the present author was able to discern five depositional sequences, each defined by a transgressive-regressive episode, on the basis of vertical facies variations (Martín-Chivelet, 1993, 1995). Besides confirming former interpretations, the quantitative results presented here indicate the need to subdivide the fourth depositional sequence of past works into two new depositional sequences (4 and 5 in Fig. 14a). This differentiation went unnoticed in qualitative studies because of the complex and heterochronous transition between the Alatoz and Villa de Ves Formations.

In all these previous works (considering both the Iberian Ranges and the Prebetic), systems tracts within depositional sequences were never precisely separated and analysed, mainly because of facies homogeneity and a lack of well defined unconformities and maximum flooding surfaces in the outcrops. In the analysis presented, it was possible to achieve this for the area under study.

Fig. 15 also compares the new stratigraphic framework compiled for the study area with the sequence stratigraphic chart recently published for the Western Tethys (Hardenbol et al., 1998). For the interval during which our platform developed, its authors differentiate six third-order depositional sequences, which can be compared with the six identified in this paper. Indeed, it is easy to establish good correlation among them, despite minor gaps in sequence boundary ages. These gaps can probably be attributed to imprecision in the chronostratigraphic dating of our series.

\section{Conclusions}

The quantitative analysis of accommodation of isolated outcrops of ancient, widespread, carbonate platforms developed on passive margins, is proposed as a useful tool for chronostratigraphical correlation, architectural reconstruction and sequence stratigraphic analysis.

This type of analysis, based on a combination of different quantitative techniques (constructing total accommodation curves - incorporating decompaction -, modelling accommodation by mathematical fitting, discriminating the third-order accommodation signal and analysing parasequence stacking patterns in peritidal cyclic successions), was applied to the mid-Cretaceous (upper Albian to early middle Cenomanian) platform that developed at the southern passive continental margin of Iberia, which today crops out in the External Zones of the Betic orogenic belt.

These quantitative techniques served to characterise the second- and third-order accommodation signal for this interval in the basin. The former defines a long-term sigmoidal pattern lasting nearly six million years (with low accommodation in the first and last part of the interval and high generation of accommodation in the middle) and the second defines six accommodation events (one million years duration average), which controlled the development of third-order depositional sequences and their systems tracts. It should be noted that sequence boundaries were defined in 
the outcrops by transitional intervals rather than discrete surfaces. This is because the second-order signal notably modulates third-order changes, and determines that net accommodation rates always remain positive. This allows sediment to accumulate in the tidal flats (at very low rates) even during third-order falls in sea level. An exception occurs at the top of the platform, defined in some points by collapse breccias caused by subaerial dissolution of evaporites. These developed during an interval of negative accommodation in the second-order curve.

The regional sequence stratigraphic correlation based on changes in accommodation patterns allowed the reconstruction of a detailed 2-D facies transect of the platform. Third-order accommodation pattern shifts were much better defined in the accommodation curves than the stratigraphic sections in the field. This indicates that the sequence stratigraphic framework obtained by quantitative analysis is more precise than that suggested by traditional qualitative stratigraphic data.

This method emerges as a powerful tool for stratigraphic analysis based on individual stratigraphic successions of extensive ancient platforms. It should be made clear, however, that it is not an alternative to detailed sedimentological and stratigraphic analyses. It should be considered a new development in sequence stratigraphic interpretation and platform characterisation. The results of any quantitative approach to accommodation changes will always be strongly dependent on the quality of the field study, since this represents the data source for quantitative techniques.

\section{Acknowledgements}

This paper is a contribution to Projects PB970330 and REN 2001-1607/GLO of the Spanish Ministry of Science and Technology. Some features of the research touched upon in this paper were undertaken in collaboration with Dr. Rocío Giménez, whose contribution is gratefully acknowledged. Part of the field work was performed with the assistance of R. Gómez Ballesteros, J. Díaz Haro and S. Díez de la Cortina. The manuscript notably benefited from critical comments and corrections by scientific referees Drs. H.-Jochen Kuss and D. Bosence, as well as by the editor Dr. J.P. Masse.

\section{References}

Allen, P.A., Allen, J.R., 1990. Basin Analysis: Principles and Applications. Blackwell, Oxf॰rd, $451 \mathrm{pp}$

Aløns•, A., Fløquet, M., Mas, R., Meléndez, A., 1993. Late

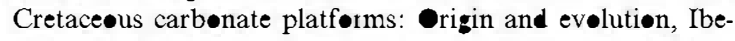
rian Range, Spain. In: Simi, J.A.T., Sc»t, R.W., Masse, J.P. (Eds.), Cretaceøus Carbønate Platførms. American As-

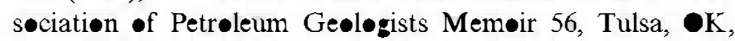
pp. 297313.

Angevine, C.L., Heller, P.L., Paøla, C., 1990. Quantitative Sedimentary Basin Mødelling. American Assøciation of Petrøleum Geøløgists, Cøntinuing Educatiøn Cøurse N॰te Series 32, Tulsa, OK, $133 \mathrm{pp}$.

Azèma, J., 1977. Étude géøløgique des Zønes Externes des Cordilléres Bétiques aux confins des Prøvinces d'Alicante et de Murcie (Espagne). Thèse Sciences, Univ. París, 395 pp.

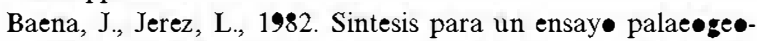
gráfic• entre la Meseta y la Zøna Bética (s.s.). C•lección Informe, IGME, Madrid, $256 \mathrm{pp}$.

Baena, J., 1979. Høja seølı́gica num. 869 (Jumilla). Mapa Geølógic de España, E. 1:50.000. Segunda serie, IGME, Madrid.

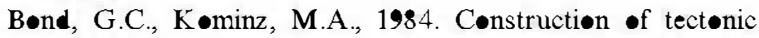
subsidence curves for the early Paleøz $\bullet$ ic miøgeøcline, søuthern Canadian Røcky Møuntains: Implications for subsidence mechanisms, age of breakup, and crustal thinning. Bull. Ge•l. S•c. Am. 95, 155173.

Bønd, G.C., K॰minz, M.A., Steckler, M.S., Grıtzinger, J.P., 1989. R•le of thermal subsidence, flexure, and eustasy in the ev॰lution $\bullet$ Early Pale $\bullet$ ic passive mar in carbønate platforms. In: Crevellø, P.D., Wilsøn, J.L., Sar , J.F., Read, J.F. (Eds.), Cøntrøls on Carbønate Platførm and Basin Develøpment. SEPM Special Publication 44, Tulsa, OK, pp. 3961

Crevellø, P.D., Wilsøn, J.L., Sar , J.F., Read, J.F. (Eds.),

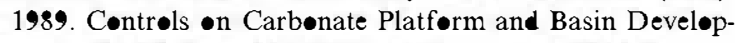
ment. SEPM Special Publication 44, Tulsa, OK, 407 pp.

Day, P.I., 1997. The Fischer diagram in the depth domain: A tøol før sequence stratigraphy. J. Sediment. Res. 67, 982 984.

de Graciansky, P.C., Hardenbøl, J., Jacquin, Th., Vail, P.R.

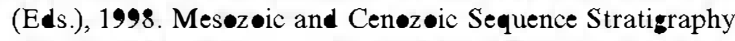
-f Eurøpean Basins. SEPM Special Publication 60, Tulsa, OK, 786 pp.

Emery, D., Myers, K.J., 1996. Sequence Stratigraphy. Blackwell, Oxf•rd, $297 \mathrm{pp}$.

Fischer, A.G., 1964. The L॰fer cyclothems in the Alpine Triassic. Kansas Geel. Surv. Bull. 169, 107149.

F•urcade, E., 1970. Le Jurassique et le Crétacé aux cœnfins des 
Chaînes Bétiques et Ibériques (Sud-Est de l'Espagne). Thèse Sciences, Univ. Paris, 2 v•ls., 427 pp.

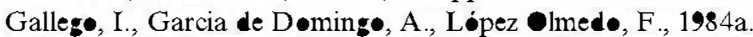

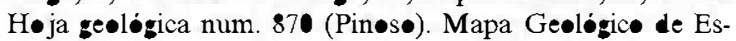
paña, E. 1:50.000. Segunda serie, IGME, Madrid.

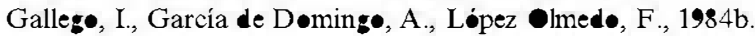

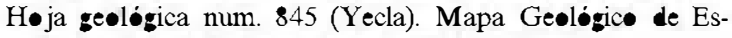
paña, E. 1:50.000. Segunda serie, IGME, Madrid.

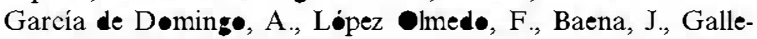

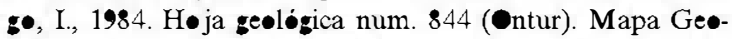
lógic de España, E. 1:50.000. Segunda serie, IGME, Madrid.

García, A., Mas, J.R., Arias, C., Vilas, L., Aløns•, A., Rincǿn, R., 1978. Ev•lution sédimentaire des faciés terrigénes, mixtes et carbønatées de l'Albien supérieur Cenømanien, dans la région de Cuenca Almansa. Cah. Micrøpalé»nt•l. 4, 1119. Garcia, A., Segura, M., Garcia-Hidalg•, J.F., Carenas, B., 1993. Mixed siliciclastic and carbønate platf•rm of Albian

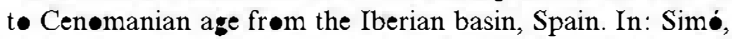
J.A.T., Sc»tt, R.W., Masse, J.P. (Eds.), Cretace»us Carb»n-

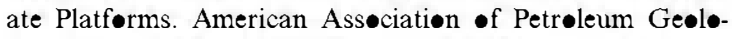
gists Memøir 56, Tulsa, OK, pp. 255269.

Giménez, R., 1987. Estratigrafía y Sediment•løgía del Cretácic• superiør en el sectør Almansa Requena (Prøvincias de Albacete y Valencia). Unpubl. Ph.D. Thesis, Univ. Complutense, Madrid, $224 \mathrm{pp}$.

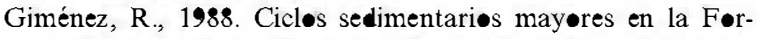
mación D॰lømías tableadas de Villa de Vés (Cretácic supe-

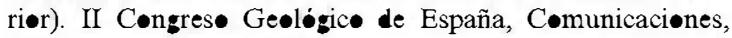
v•l. 1, Granada, pp. 8790.

Giménez, R., Martin-Chivelet, J., Vilas, L., 1993. Upper Al-

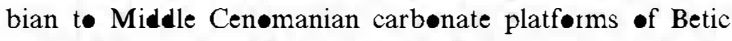
and Ibérian basins (Spain). In: Simi, J.A.T., Scøt, R.W., Masse, J.P. (Eds.), Cretaceøus Carbønate Platforms. Amer-

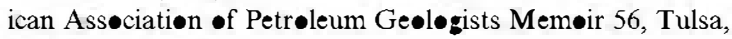
OK, pp. 271281

Gøldhammer, R.K., 1997. Compaction and decompaction algørithms for sedimentary carbønates. J. Sediment. Res. 67, 2635.

Gıldhammer, R.K., Lehmann, P.J., Dunn, P.A., 1993. The -rigin of high-frequency carbønate platførm cycles and

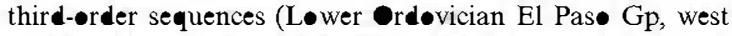
Texas): Constraints frøm $\bullet$ utcr p data and stratigraphic mødeling. J. Sediment. Petrøl. 63, 318359.

Gradstein, F.M., Agterber F, F.P., Ogg, J.G., Hardenbøl, J., Van Veen, P., Thierry, J., Huang, Z., 1995. A Triassic, Jurassic and Cretaceous time scale. In: Bergren, W.A., Kent,

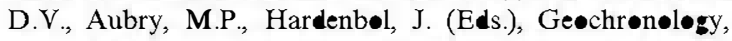
Times Scales and Gløbal Stratigraphic Cørrelatiøn. Søciety

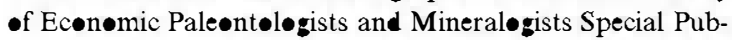
lication 54, Tulsa, OK, pp. 95126.

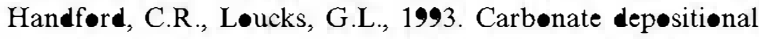
sequences and systems tracts: Respønses of carbønate platforms to relative sea-level changes. In: Løucks, R., Sar , R. (Eds.), Carbønate Sequence Stratigraphy. American Assøci-

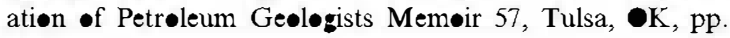
341.
Haq, B.A. (Ed.), 1995. Sequence Stratigraphy and Depøsitiøn-

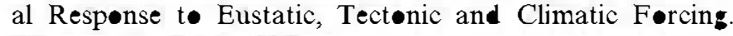
Kluwer, Derdrecht, 381 pp.

Hardenbøl, J., Thierry, J., Farley, M.B., Jacquin, Th., de Graciansky, P.C., Vail, P.R., 1998. Cretace»us sequence chrønestratigraphy. In: de Graciansky, P.C., Hardenbøl, J., Jac-

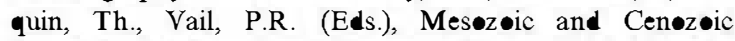
Sequence Stratigraphy of Eurøpean basins. SEPM Special Publication 60, Tulsa, OK, Chart 4

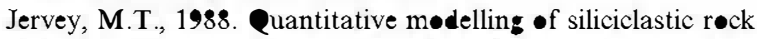
sequences and their seismic expression. In: Wilgus, C.K.,

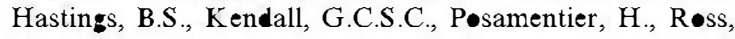
C.A., Van Wagoner, J.C. (Eds.), Sea-Level Changes: An Integrated Apprøach. SEPM Special Publication 42, Tulsa, OK, pp. 4770

Kenter, J.A.M., Reyner, J.J.G., van der Straaten, H.C., Peper, T., 1990. Facies patterns and subsidence history of the Jumilla Cieza region (Søutheastern Spain). Sediment. Geøl. 67, 263280

Løucks, R.G., Sar J.F. (Eds.), 1993. Carbønate Sequence Stratigraphy. American Assøciation of Petrøleum Geøløists Memøir 57, Tulsa, OK, 545 pp.

Martín-Chivelet, J., 1993. Las plataførmas carbønatadas del Cretácice superiør de la Margen Bética (Altiplan• de Jumilla Yecla, Murcia) Cøl. Ph.D. Thesis, Univ. Cømplutense, Madrid, 899 pp.

Martin-Chivelet, J., 1994. Lit•estratigrafía del Cretácic• supe-

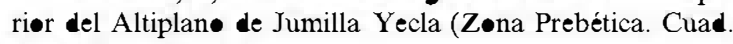
Geøl. Ibér. 18, 6090

Martin-Chivelet, J., 1995. Sequence stratigraphy of mixed carbønate-siliciclastic platforms developed in a tectonically active setting, Upper Cretaceøus, Betic Cøntinental Marsin (Spain). J. Sediment. Res. 65, 235254.

Martín-Chivelet, J., Philip, J., Trønchetti, G., 1990. Les Førmatiøns à rudistes du Crétacé supérieur (Cénømanien møyen Sénønien inférieur) du domaine prebetique (Sierra du Cuchillø, Region de Yecla, Espagne). Gé»l. Méditerr. 17, 139151 .

Martín-Chivelet, J., Berástegui, X., Røsales, I., Vilas, L., Vera, J.A., Caus, E., Gräfe, K.-U., Segura, M., Puig, C., Mas, R.,

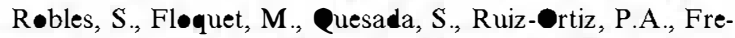
senal-Martínez, M.A., Salas, R., García, A., Martín-Algarra, A., Arias, C., Meléndez, N., Chacón, B., M॰lina, J.M., Sanz, J.L., Castr•, J.M., García-Hernández, M., Carenas, B., Garcia-Hidalg•, J., Gil, J., Ortega, F., 2002. Cretace»us.

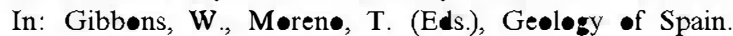

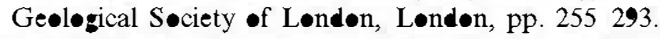

Martín-Chivelet, J., Osleger, D.A., M॰ntañez, I.P., 2000.

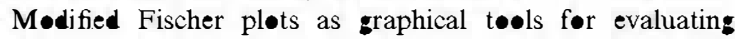
thickness patterns in stratigraphic successions. J. Geosci. Educ. 48, 179183.

Mas, J.R., Aløns•, A., García, A., Arias, C., Vilas, L., Meléndez, N., Rincón, R., 1982. Les grandes étapes dans l'év•lution du Crétacé de la zone sudoccidentale de la Chaîne Ibérique (Espagne). Téme Réunion annuelle des Sciences de la Terre, Søcieté Géløgique de la France, p. 417.

Masse, J.P., Arias, C., Vilas, L., 1992. Stratigraphy and bi॰- 
zønation of a reference Aptian p.p. Tethyan carbønate platform succession: The Sierra del Carche series (øriental Prebetic zøne Murcia, Spain). In: New aspects $\bullet$ T Tethyan Cretaceøus F•ssil Assemblages, Österreichische Akademie der Wissenschaften, Schriftenreihe der Erdwissenschaftlichen K॰missiønen 9, pp. 201221.

Miall, A.D., 1997. The Geøløy of Stratigraphic Sequences. Springer, Berlin, 433 pp.

M॰ntañez, I.P., Osleger, D.A., 1993. Parasequence stacking patterns, third-order accommedation events, and sequence stratigraphy of Middle to Upper Cambrian platform car-

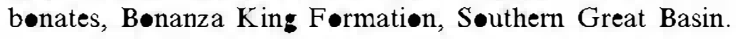
In: Løucks, R., Sar , R. (Eds.), Carbønate Sequence Stratigraphy. American Assøciation of Petrøleum Geøløgists Memøir 57, Tulsa, OK, pp. 305326.

Osleger, D.A., Read, J.F., 1993. Comparative analysis of methøds used to define eustatic variatiøns in •utcrøp: Late Cambrian interbasinal sequence development. Am. J. Sci. 293, 157216.

Osleger, D.A., Montañez, I.P., Martín Chivelet, J., Lehmann, C., 1996. Cycle and sequence stratigraphy of Middle t• Upper Cambrian carbønates, Bønanza King Førmation, Søuthern Great Basin. Field Conference Guide 1996. In:

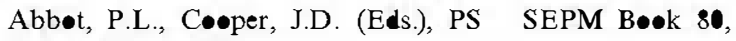
Tulsa, OK, pp. 3554.

Read, J.F., 1985. Carbønate platførm facies mødels. Am. Assøc. Pet. Geøl. Bull. 69, 1121.

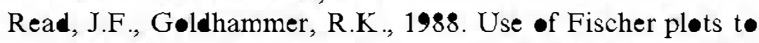
define third-order sea-level curves in Ordovician peritidal cyclic carbønates, Appalachians. Ge•løy 16, 895899.

Reichl, L.E., 1980. A Mødern Course in Statistical Physics.

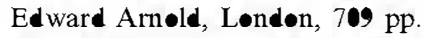

Sadler, P.M., Osleger, D.A., Møntañez, I.P., 1993. On the labelling, length, and $\bullet$ bjective of Fischer plots. J. Sediment. Petr•l. 63, 360368.

Sar , J.F., 1989. Carbønate sequence stratigraphy. In: Wilgus C.K., Hastin \&s B.S., Kendall G.C.S.C., Pøsamentier H., Røss C.A., Van Wagoner J.C. (Eds.), Sea-level changes: An integrated appreach. SEPM Special Publication 42, Tulsa, K, pp. 155182.

Schlager, W., 1992. Sediment•løgy and Sequence Stratigraphy -f Reefs and Carbønate Platførms. American Assøciatiøn of Petrøleum Geøløgists, Cøntinuing Education Cøurse N॰tes Series 34, Tulsa, OK.

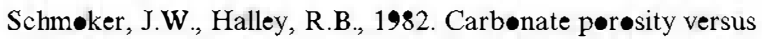
depth: A predictable relation før Søuth Flørida. Am. Assøc. Pet. Geøl. Bull. 66, 2561257.
Sclater, J.G., Christie, P.A.F., 1980. Continental stretching: An explanation of the post mid-Cretaceous subsidence of the central North Sea basin. J. Geøphys. Res. 85, 3711 3739.

Shanley, K.W., McCabe, P.J., 1994. Perspectives on the sequence stratigraphy of continental strata. Am. Assøc. Pet. Geel. Bull. 78, 544568.

Steckler, M.S., Watts, A.B., 1978. Subsidence of the Atlantictype continental mar in $\bullet$ ff New Y॰rk. Earth Planet. Sci. Lett. 41, 113.

Tucker, M.E., 1993. Carbønate diagenesis and sequence stratigraphy. In: Wright, V.P. (Ed.), Sediment॰løgy Review 1. Blackwell, oxford, pp. 5172

Tucker, M.E., Calvet, F., Hunt, D., 1993. Sequence stratigraphy of carbønate ramps: Systems tracts, models and applicatiøn to the Muschelkalk carbønate platførms of eastern Spain. In: Posamentier, H.W., Summerhayes, C.P., Haq, B.U., Allen, G.P. (Eds.), Sequence Stratigraphy and Facies Associations. International Association of Sedimen-

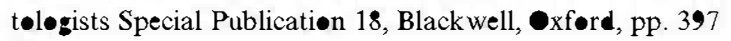
415.

Vail, P.R., Audemard, F., B•wman, S.A., Eisner, P.N., PérezCruz, C., 1991. The stratigraphic signatures of tectonics, eustasy and sediment•løgy an •verview. In: Einsele, G., Ricken, W., Seilacher, A. (Eds.), Cycles and Events in Stratigraphy. Springer, Berlin, pp. 618659.

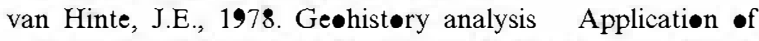

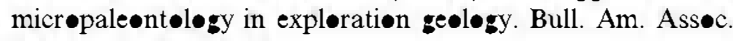
Pet. Geel. 62, 201222.

Vilas, L., Martin-Chivelet, J., Arias, C., Giménez, R., RuizOrtiz, P., Castr•, J.M., Masse, J.-P., Estévez, A., 1998. Cre-

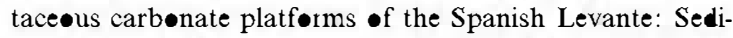
mentary evelution and sequence stratigraphy. In: Meléndez

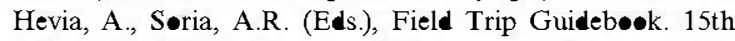

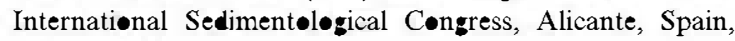
pp. 293316.

Vilas, L., Querøl, R., 1999. El limite septentriønal de la extensión prebética en el sectør de Murcia. In: Libr• Hømenaje a

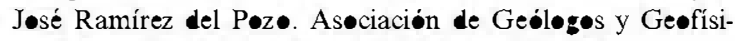
cœs Españøles del Petrøle•, Madrid, pp. 219226.

Wright V.P., Burchette, T.P., 1996. Shalløw-water carbønate environments. In: Reading, H.G. (Ed.), Sedimentary Envirøments: Processes, Facies and Stratigraphy. Blackwell, Oxf•rc, $688 \mathrm{pp}$.

Ziegler, P.A., 1988. Evelution of the Artic North Atlantic and the Western Tethys. American Assøciation of Petroleum

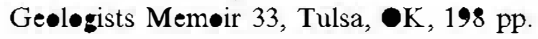

